\title{
The fate of Salmonella Tennessee and Salmonella Typhimurium in peanut butter subjected to electron beam irradiation
}

Andrea Lynn Hvizdzak

West Virginia University

Follow this and additional works at: https://researchrepository.wvu.edu/etd

\section{Recommended Citation}

Hvizdzak, Andrea Lynn, "The fate of Salmonella Tennessee and Salmonella Typhimurium in peanut butter subjected to electron beam irradiation" (2009). Graduate Theses, Dissertations, and Problem Reports.

4478.

https://researchrepository.wvu.edu/etd/4478

This Thesis is protected by copyright and/or related rights. It has been brought to you by the The Research Repository @ WVU with permission from the rights-holder(s). You are free to use this Thesis in any way that is permitted by the copyright and related rights legislation that applies to your use. For other uses you must obtain permission from the rights-holder(s) directly, unless additional rights are indicated by a Creative Commons license in the record and/ or on the work itself. This Thesis has been accepted for inclusion in WVU Graduate Theses, Dissertations, and Problem Reports collection by an authorized administrator of The Research Repository @ WVU. For more information, please contact researchrepository@mail.wvu.edu. 


\title{
THE FATE OF SALMONELLA TENNESSEE AND SALMONELLA TYPHIMURIUM IN PEANUT BUTTER SUBJECTED TO ELECTRON BEAM IRRADIATION
}

\author{
Andrea Lynn Hvizdzak
}

Thesis submitted to the Davis College of Agriculture, Forestry, and Consumer Sciences

at West Virginia University in partial fulfillment of the requirements for the degree of

\author{
Master of Science \\ in \\ Animal and Nutritional Sciences
}

\author{
Kristen Matak, Ph.D., Committee Chairperson \\ Jacek Jaczynski, Ph.D. \\ P. Brett Kenney, Ph.D.
}

Animal and Nutritional Sciences

\author{
Morgantown, West Virginia
}

2009

Keywords: electron beam, food irradiation, water activity, Salmonella Tennessee, Salmonella Typhimurium 


\begin{abstract}
The Fate of Salmonella Tennessee and Salmonella Typhimurium in Peanut Butter Subjected To Electron Beam Irradiation
\end{abstract}

Andrea Lynn Hvizdzak

Peanut butter and peanut paste products were implicated as the vehicle of contamination in an outbreak of Salmonella Typhimurium that began in September 2008 and in the November 2006 outbreak of Salmonella Tennessee; therefore based on the apparent need for intervention measure, the purpose of this research was to evaluate the effectiveness of non-thermal electron beam irradiation for reduction of Salmonella serovars Tennessee (ATCC 10722) and Typhimurium (ATCC 14028) in creamy peanut butter. Each strain was studied independently. Peanut butter samples were inoculated with approximately $7.0 \mathrm{log}$ CFU/g of Salmonella and exposed to e-beam doses ranging from 0-3.1 kGy. Doses were confirmed using film dosimetry. Survivors were enumerated by standard spread-plating on non-selective (tryptic soy agar; TSA) and selective (xylose lysine deoxycholate agar; XLD) media. Microbial counts (CFU/g) were log-converted and the slopes of the respective survivor curves were determined by linear regression. $\mathrm{D}_{10}$-values were calculated as the negative reciprocal of the slope of the survivor curve and were reported as mean values \pm standard deviation. One-way analysis of variance and Tukey's honestly significant difference test were used to determine differences. $\mathrm{D}_{10}$-values show that Salmonella Typhimurium was more resistant $(0.82 \pm 0.02$ and $0.73 \pm 0.01 \mathrm{kGy}$ on TSA and XLD, respectively) than Salmonella Tennessee $(0.72 \pm 0.02$ and $0.60 \pm 0.01 \mathrm{kGy}$ on TSA and $\mathrm{XLD}$, respectively) to e-beam irradiation $(P<0.05)$. The recovery on growth and selective media was different $(P<0.05)$, indicating cell injury. Microbial analyses were conducted after $4,6,8$, and $14 \mathrm{~d}$ of storage. The rate of microbial decline was significant over the $14 \mathrm{~d}$ storage period $(P<0.05)$; the greatest reductions were seen at target e-beam dose $2.5 \mathrm{kGy}$ at day $14(P<0.05)$. Salmonella Tennessee and Salmonella Typhimurium mean survivor populations exposed to ebeam irradiation in peanut butter will decline overtime. E-beam irradiation may be an effective processing step for the non-thermal inactivation of Salmonella in peanut butter. 


\section{DEDICATION}

I wish to dedicate this thesis to my parents, Ed and Faye Hvizdzak. Their love, encouragement, guidance, and support made this possible. 


\section{ACKNOWLEDGMENTS}

I would like to take this opportunity to thank Dr. Kristen Matak for her patience and assistance in guiding me through my masters. I would like to thank Dr. Jacek Jaczynski and Dr. P. Brett Kenney for their advice, encouragement, and feedback in evaluating this thesis and serving as members of my committee. I would also like to thank Sarah Beamer for all of her assistance in the laboratory. This work would not have been completed without her help.

Lastly, I would like to thank Carl A. Zinn and Sterigentics for allowing me to use their facilities and the electron beam accelerator. 


\section{TABLE OF CONTENTS}

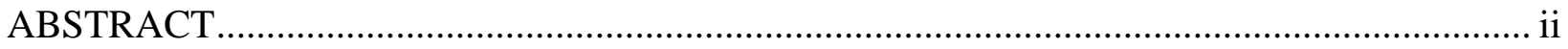

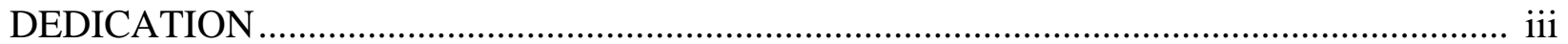

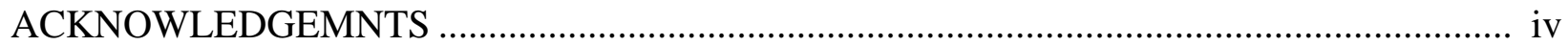

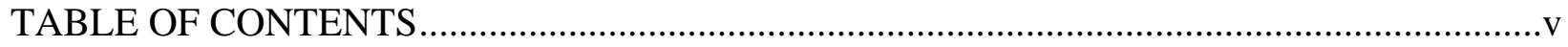

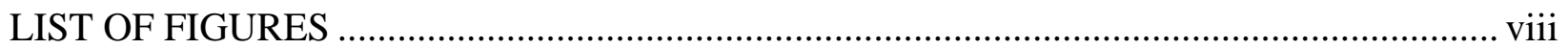

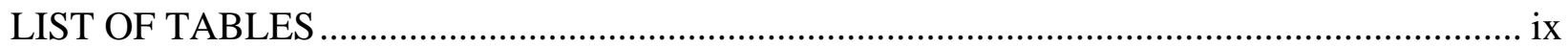

\section{CHAPTER 1}

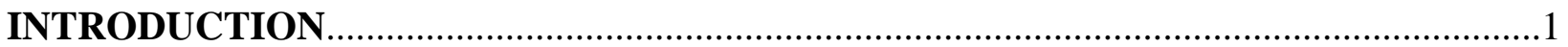

\section{CHAPTER 2}

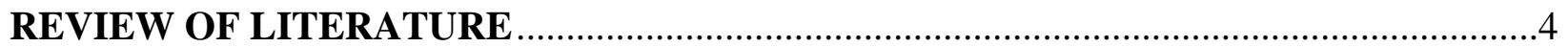

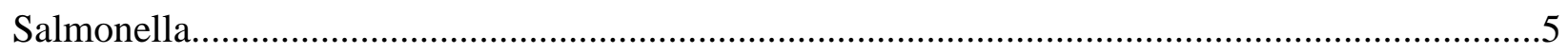

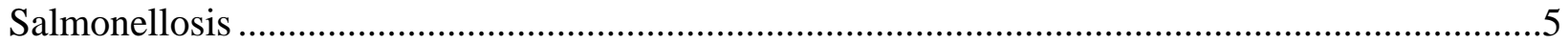

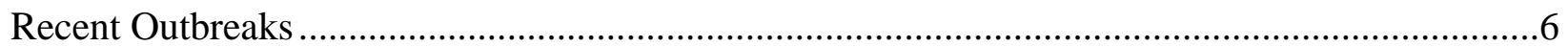

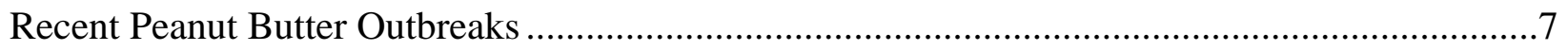

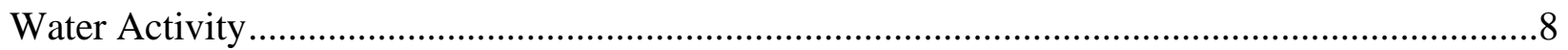

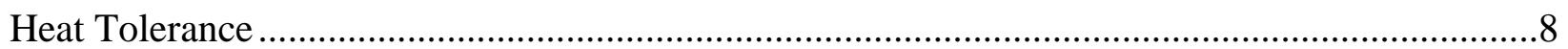

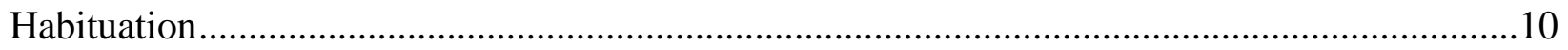

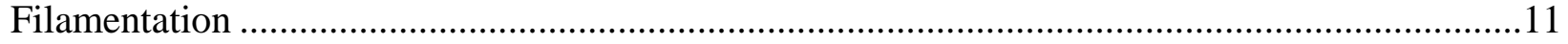

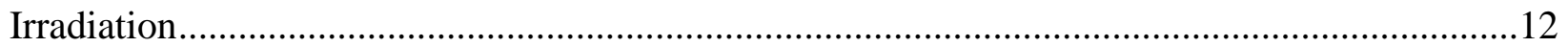

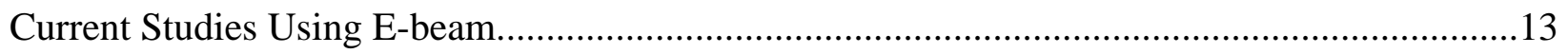

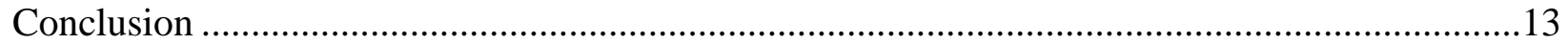

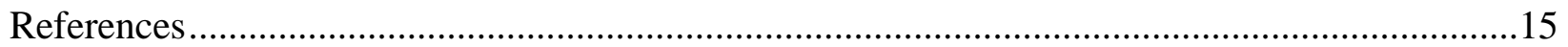




\section{CHAPTER 3}

Use of Electron Beam Irradiation for the Reduction of Salmonella enterica Serovars

Typhimurium and Tennessee in Peanut Butter

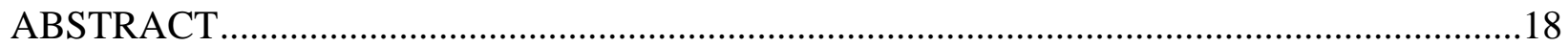

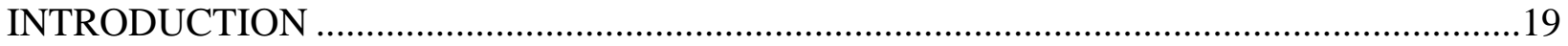

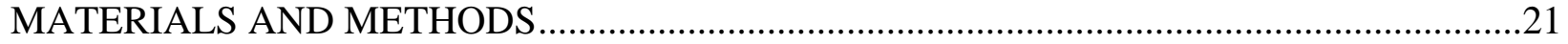

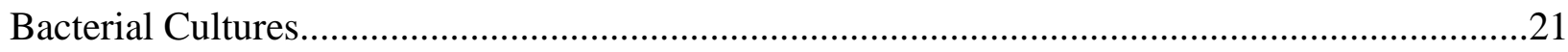

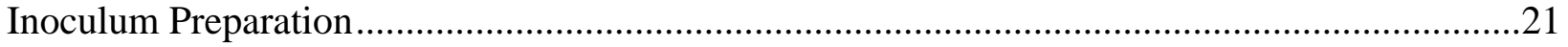

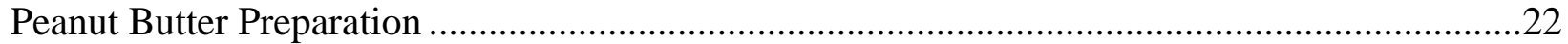

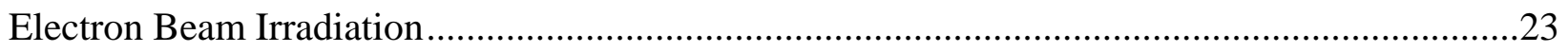

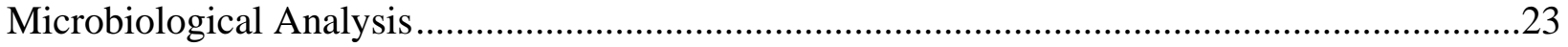

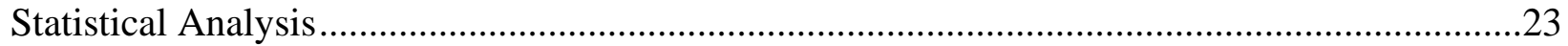

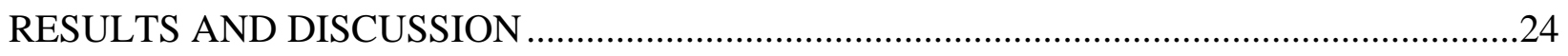

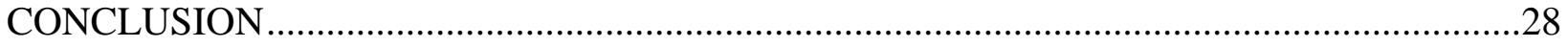

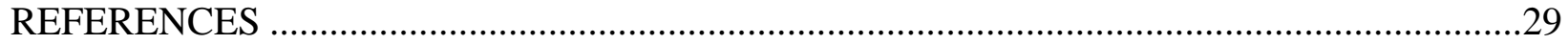

\section{CHAPTER 4}

Fate of Salmonella enterica Serovars Typhimurium and Tennessee in Peanut Butter after

\section{Electron Beam Exposure}

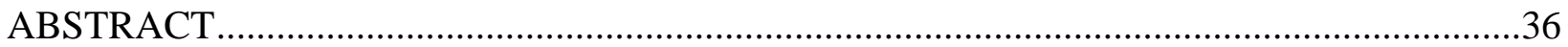

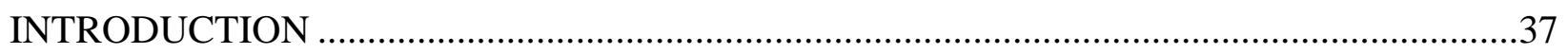

MATERIALS AND METHODS...........................................................................................40

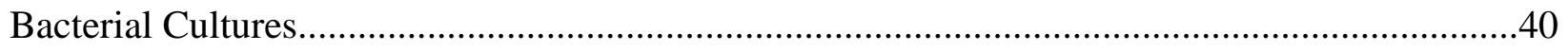

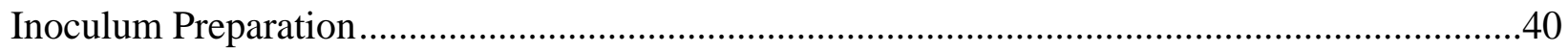

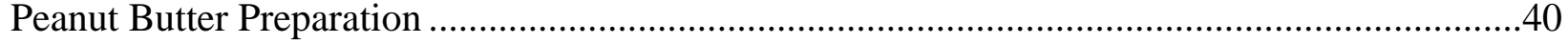

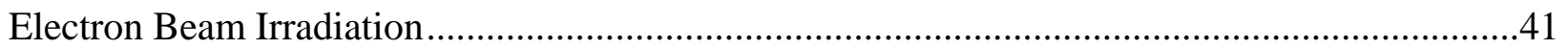

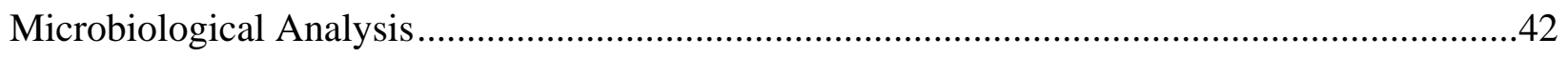

Statistical Analysis..............................................................................................................42 


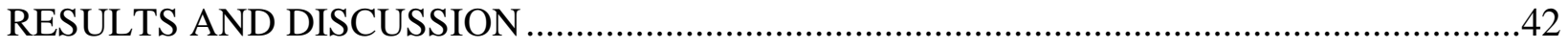

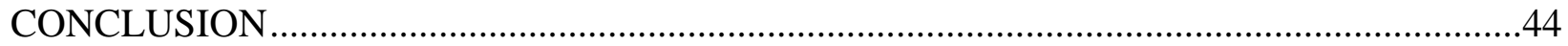

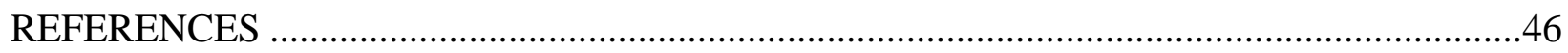

\section{APPENDICES}

Appendix A Survivor Curve for Salmonella Tennessee on TSA .............................................55

Appendix B Survivor Curve for Salmonella Tennessee on XLD ..............................................56

Appendix C Survivor Curve for Salmonella Typhimurium on TSA ..........................................57

Appendix D Survivor Curve for Salmonella Typhimurium on XLD ........................................58

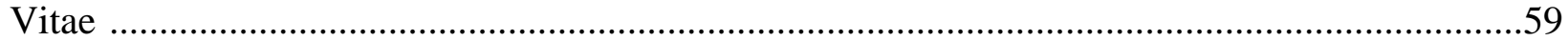




\section{List of Figures}

\section{Chapter 1}

Figure 1. Survivor curve for Salmonella Tennessee in peanut butter subjected to electron beam on TSA and XLD.

Figure 2. Survivor curve for Salmonella Typhimurium in peanut butter subjected to electron beam on TSA and XLD.

\section{Chapter 2}

Figure 1. Salmonella Tennessee survivors in peanut butter subjected to electron beam on TSA over a 14 day period.

Figure 2. Salmonella Tennessee survivors in peanut butter subjected to electron beam on XLD over a 14 day period.

Figure 3. Salmonella Typhimurium survivors in peanut butter subjected to electron beam on TSA over a 14 day period.

Figure 4. Salmonella Typhimurium survivors in peanut butter subjected to electron beam on XLD over a 14 day period. 


\section{List of Tables}

\section{Chapter 1}

Table 1. Survival of Salmonella Tennessee and Salmonella Typhimurium (mean log $\mathrm{CFU} / \mathrm{g} \pm \mathrm{SD}$; $\mathrm{n}=6$ ) in peanut butter plated on non-selective tryptic soy agar (TSA) and selective xylose lysine deoxycholate agar (XLD).

Table 2. $\mathrm{D}_{10}$-values of Salmonella serotypes Tennessee and Typhimurium in peanut butter exposed to e-beam irradiation.

\section{Chapter 2}

Table 1. Survival curves of Salmonella Tennessee populations (mean log $\mathrm{CFU} / \mathrm{g} \pm \mathrm{SD} ; \mathrm{n}=6$ ) in peanut butter plated on non-selective tryptic soy agar (TSA.)

Table 2. Survival curves of Salmonella Tennessee populations (mean log CFU/g $\pm \mathrm{SD}$; $\mathrm{n}=6$ ) in peanut butter plated on selective xylose lysine deoxycholate agar (XLD).

Table 3. Survival curves of Salmonella Typhimurium populations (mean $\log \mathrm{CFU} / \mathrm{g} \pm \mathrm{SD}$; $\mathrm{n}=6$ ) in peanut butter plated on non-selective tryptic soy agar (TSA).

Table 4. Survival curves of Salmonella Typhimurium populations (mean log CFU/g $\pm \mathrm{SD} ; \mathrm{n}=6$ ) in peanut butter plated on selective xylose lysine deoxycholate agar (XLD). 


\section{CHAPTER 1}

\section{INTRODUCTION}

Each year in the United States there are approximately 76 million cases of foodborne disease, resulting in an estimated 325,000 hospitalizations and 5,000 deaths. Every year $\$ 37.1$ and \$23 billion are lost in production and medical expenses, respectively (CDC 2007). There are seven major foodborne pathogens responsible for these cases, and one of the seven implicated pathogens is Salmonella. Over 2,400 serotypes of the genus Salmonella are known to exist. Salmonellosis is the second most reported foodborne illness. The Outbreaks are commonly associated with foods of animal origin, including poultry, eggs, and meat (FDA $2009^{\mathrm{a}}$ ). The Center for Disease Control and Prevention examines aspects of production as well as food service in order to help eradicate foodborne illnesses. A standardized approach was established to food safety referred to as the Hazard Analysis and Critical Control Points. These were developed in hopes to improve the safety of food products (FDA $2009^{b}$ ). Despite advances in food safety, foodborne pathogens continue to be of concern in the United States. The most recent outbreaks of Salmonella implicate peanut butter and peanut butter products (CDC 2009). Despite prescribed pasteurization, peanut butter continues to harbor infectious Salmonella cells. Researchers believe Salmonella survival in peanut butter is recognized to unique attributes such as: a low water activity $\left(\mathrm{a}_{\mathrm{w}}\right)$, high fat content, $\mathrm{pH}$, and iron composition. Distinctive features of Salmonella in these environments are its ability to adapt to its environment through filamentation, habituation, and protein degradation. Without an alternative method of effective microbial reduction, peanut butter and peanut butter products will continue to be a food safety concern. 
As a result of the need for a more effective intervention, the objective of this thesis was to evaluate the effect of e-beam irradiation on the reduction of Salmonella Tennessee and Salmonella Typhimurium at a target dose of $10^{7} \log \mathrm{CFU} / \mathrm{g}$ in peanut butter, and to look at the fate of these strains over time. 


\section{References}

Centers for Disease Control and Prevention, 2007. Multistate Outbreak of Salmonella Serotype Tennessee Infections Associated with Peanut Butter-United States, 2006-2007. Morbidity and Mortality Weekly Report 56, 521-525.

Centers for Disease Control and Prevention, 2009. Investigation Update: Outbreak of Salmonella Typhimurium Infections, 2008-2009. http://www.cdc.gov/salmonella/typhimurium/

${ }^{\mathrm{a}}$ Food and Drug Administration http://www.fda.gov/default.htm. February 2009.

${ }^{\mathrm{b}}$ Food and Drug Administration Center for Food Safety and Applied Nutrition http://vm.cfsan.fda.gov February 2009. 


\section{CHAPTER 2}

\section{REVIEW OF LITERATURE}

Salmonellosis infects about 2 to 4 million people annually. In the past decade there has been a rise in Salmonella infections. In the United States Salmonella is responsible for 15\% of all food poisonings. Salmonellosis is also the second most common bacterial foodborne illness reported (CDC 2007). Despite scientific efforts there is still little known about how Salmonella cells survive in certain low water activity foods, such as, peanut butter, chocolate, and various processed foods. There does, however, appear to be evidence of a connection between heat tolerance and low water activity for Salmonella cells and the way they survive and grow (Mattick et al 2001). Scientific research demonstrates this connection as well as an interaction of pre-exposed cells to osmotic stress (Mattick et al $2000^{\text {a }}$ ). Salmonella cells are unique particularly in the way they are able to adapt to their environment. Due to recent bacterial outbreaks, the food industry is looking for alternatives to thermal pasteurization for foods that have a low water activity and high fat content like peanut butter. Ionizing radiation may be an effective alternative. Irradiation is a process which uses ionizing radiation to reduce microorganisms present in or on food and food products. Irradiation is approved by the Federal Drug Administration for meat, spices, fresh fruits, and vegetables (FDA 2009). The bactericidal effect of irradiation for colloidal systems has yet to be studied. Research into the effect of irradiation on Salmonella in peanut butter may prove to beneficial for the safety of peanut butter processing. This in turn may allow food industries to adopt a more effective process for the elimination of harmful microorganisms. 


\section{Salmonella}

There are over 2,000 different species of Salmonella. The differences that can be identified between species are cell structure, specifically $\mathrm{O}$ and $\mathrm{H}$ antigens in Salmonella species. The $\mathrm{H}$ antigen represents the flagellar antigen while $\mathrm{O}$ represents the somatic antigen. $\mathrm{O}$ antigens are important because they occur on the surface of the outer membrane. They are determined by sugar sequence and are responsible for determining the virulence of the organism. $\mathrm{O}$ antigens are the body of the microorganism and are characterized by the number and type of sugars in the outer core. $\mathrm{O}$ antigens are also heat stable. The $\mathrm{H}$ antigens are heat labile and are found in the flagellar, or tail portion of the microorganism. The $\mathrm{H}$ antigens are unique because they have the ability to change forms. Species and serovars are categorized as A, B, C, etc. according to similarities in the content of the O antigen (Rubin and Weinstein 1977).

\section{Salmonellosis}

Salmonella infections cause salmonellosis. Salmonella infections begin when one of the over 2,000 species of Salmonella are ingested. Ingestion of Salmonella is typically from undercooked eggs, poultry, and meat products. The Salmonella bacteria are able to endure the acidity of the stomach and travel to the small intestine. Once in the small intestine they adhere to the lining of the small intestine and begin their life cycle. The Salmonella cells are then shed through the feces. Symptoms usually arise within 12 to 72 hours after ingestion and usually last four to seven days. The infections cause various symptoms such as, diarrhea, stomach cramps, and fever (CDC 2007). 


\section{Recent Outbreaks}

Salmonellosis is an important medical problem. Every year in the United States Salmonella infects about 40,000 individuals. Although most cases are mild, causing only diarrhea and cramps, some cases can progress and eventually lead to death. This tends to happen in individuals with a weakened immune system such as children and elderly (CDC 2007). The Centers for Disease Control and Prevention in combination with the Associate of State and Territorial Epidemiologists has maintained watch over Salmonella infections in the United States since 1962. Despite their efforts little is known about the Salmonella outbreaks that have occurred. This is mainly because most cases are not reported, and of those that are little information is available to identify the source. Salmonella outbreaks have been occurring for many years despite efforts to control it, the outbreaks seem to be more numerous than ever (CDC 2009).

In November 2006, a Salmonella outbreak associated with peanut butter caused 483 illnesses in 43 U.S. states (CDC 2007). In January 2009, an outbreak of Salmonella forced companies to recall more than 3,000 products associated with peanut butter. In this outbreak 691 people were sickened, including 9 deaths, in 47 U.S. states. The cause of these Salmonella outbreaks is unknown. Typical pasteurization and sterilization processes should be sufficient to eliminate pathogens; however, contamination could occur after processing. It is therefore important to study the survival characteristics of Salmonella cells, in low water activity and high fat content environments. 


\section{Recent Peanut Butter Outbreaks}

The first known and documented outbreak of Salmonella in peanut butter was documented in Australia in 1995 (Scheil et al. 1998). The first outbreak reported in The United States occurred in November 2006. The outbreak was associated with commercial jars of peanut butter. The most recent Salmonella outbreak started in November 2008 and implicated peanut butter and peanut butter paste products. In January 2009, this outbreak of Salmonella Typhimurium forced companies to recall more than 3,000 products associated with peanut butter as a common ingredient. These products included various cookies, crackers, cereals, candies, ice creams, pet treats, etc. The CDC considers this outbreak to be of special concern because of the wide range of food products that were affected (CDC 2009).

Peanut butter is typically consumed throughout the world. Peanut butter consumers span a wide range of ages including those individuals who may be more adapt to developing severe symptoms of Salmonellosis, such as, children, elderly, and those with weakened immune systems. Peanut butter has a long shelf life allowing it to be stocked in various kitchens, industries, and households for many weeks. Peanut butter is a colloidal system containing a high fat content as well as a low water activity. Salmonella is able to survive within this environment for the duration of its self life. The heating of $>70^{\circ} \mathrm{C}$ may not eliminate all the Salmonella cells possibly present in the product (CDC 2007). Salmonella cells may be introduced into peanut butter at multiple points during production. It is for this reason that non thermal safety measures for peanut butter be investigated. 


\section{Water Activity}

Water activity in a food is the water available for use, or free water. Water is extremely important in food industries because the lower the water activity the less likely the chance of microbial growth, thus leading to a longer shelf life and higher consumer acceptance. Most microorganisms are unable to survive and grow in low water activity environments. Yet, Salmonella has the ability to both survive and reproduce when water is unavailable for use (Mattick et al $2000^{\mathrm{a}}$ ).

Keiboom and others (2006) examined the morphological and physiological changes Salmonella experiences under low water activities. It was found that Salmonella does have the ability to form elongated cells which was not a result of surface effects or solute concentrations. The survival of Salmonella at low water activity increases the threat for cross contamination over a long period of time. This is mostly because these cells are capable of building a tolerance when pre exposed to certain environmental factors such as heat and solutes. These cells are then able to survive more efficiently than other cells and in turn cause more Salmonella contaminations (Keiboom et al. 2006). Knowing this it is important to examine the aspects and use of temperatures, specifically those used for pasteurization and sterilization, on Salmonella in low water activities.

\section{Heat Tolerance}

Salmonella is a rod shaped gram negative pathogenic bacterium. Salmonella is typically found in foods of animal origins, specifically beef, poultry, and eggs. Animals have a higher affinity for Salmonella species than humans. For this reason, animals are not sickened with disease the way that humans are. Salmonella is naturally occurring in the digestive tract of 
animals. This potential for cross contamination is why animal products need to be cooked to as high as $165^{\circ} \mathrm{F}$ for meat products. Cooking to certain temperatures kills Salmonella present within the food (FDA 2009). Because of this, inactivation methods have been developed to help lessen the number of active Salmonella species on food sources. These methods include different variations of thermal processing that are not as effective when it comes to eliminating Salmonella in low water activity foods such as peanut butter.

In a 2006, Shachar and Yaron studied the effectiveness of heat tolerance on three strains of Salmonella in peanut butter. They found the peanut butter pasteurization process of temperatures at $70^{\circ} \mathrm{C}$ to $75^{\circ} \mathrm{C}$ for 20 minutes to be unsuccessful in destroying the microorganism. Salmonella continued to survive even at temperatures of $90^{\circ} \mathrm{C}$ for 50 minutes (Shachar and Yaron 2006). Thermal tolerance demonstrates problems that Salmonella has on increased heat resistance in foods that have low water activities and high lipid contents. Salmonella does not exhibit growth at temperatures below $5.3^{\circ} \mathrm{C}$ or above $45^{\circ} \mathrm{C}(\mathrm{CDC} 2009)$.

Salmonella species are known to have greater heat tolerance at low $\mathrm{a}_{\mathrm{w}}$. In 2001 Mattick et al. studied the effect of temperatures on Salmonella at low water activity. Some studies have reported that heat tolerance of Salmonella can increase or decrease at low water activity (BairdParker 1970). While other studies argue that heat tolerance of Salmonella increases as the $\mathrm{a}_{\mathrm{w}}$ decreases (Kirby 1990). Mattick et al. (2001) found that Salmonella cells were more heat tolerant at low water activity; whereas, heat tolerance was not seen at temperatures below $65^{\circ} \mathrm{C}$. Mattick et al (2001) proposed that improved protein stability may play a large part into the mechanism. The ribosomes and proteins may exhibit increased heat stability at low water activities. The interaction between heat tolerance and water activity in Salmonella species proves to be unique. Salmonella demonstrates responsiveness when exposed to a stimulus. 
Recent studies have found that Salmonella grow best at a water activity of 0.99 . Ngwai and others studied Salmonella Typhimuium and Salmonella enteritidis under stressful growth conditions in hopes to better identify stress tolerances. They found that Salmonella Typhimurium did not grow well at elevated temperatures unless supplemented with iron. Peanut butter naturally has a small percentage of iron within its composition. The iron found within peanut butter may actually help to aid in the survival of Salmonella species enough to bypass the elevated temperatures that would typically destroy the bacteria (Ngwai et al. 2007). Unlike typical food products, in peanut butter Salmonella cells do not undergo protein denaturation. The environmental conditions and composition of peanut butter aid in Salmonella cells survival. This survival by the microorganism Salmonella contributes to an unsafe food product. A direct mechanism or association for the protective effects of peanut butter harboring Salmonella has yet to be identified.

\section{Habituation}

The habituation of Salmonella species at a reduced water activity and its effects on heat tolerance have been studied by Mattick et al. $\left(2000^{\mathrm{a}}\right)$. They found that despite past results and implications, protein synthesis is not likely to be the mechanism whereby Salmonella cells increase their stability. The way in which protein synthesis occurs is through the ribosome inhibitors; therefore, they theorized that the solutes used in their study held the cells at a higher osmotic stress causing them to modify their structure in order to stabilize with the environment. This, in turn, caused a higher heat tolerance (Mattick et al. $2000^{\mathrm{a}}$ ). 


\section{Filamentation}

Filamentation is the abnormal growth of bacteria in which cells continue to elongate but do not divide. This is a defect in completing replication and usually occurs under certain conditions such as high heat or osmotic stress. Salmonella enterica serovar Enteritidis and Salmonella enterica serovar Typhimurium survive at reduced $\mathrm{a}_{\mathrm{w}}$ for long periods and form filaments (Mattick et al $2000^{\mathrm{b}}$ ). Surviving filamentous cells can maintain their membrane integrity after exposure to low $\mathrm{a}_{\mathrm{w}}$ for 21 days and are able to survive disinfection more efficiently (Kieboom et al. 2006). The filamentous cells formed as a result of a biomass increase in the absence of cell division during the low $\mathrm{a}_{\mathrm{w}}$ stress. If filamentation is found to occur in foods, there are implications for low $\mathrm{a}_{\mathrm{w}}$ food products. A single contaminating Salmonella cell could continue to replicate, in turn leading to infection after consumption (Mattick et al. $2000^{\mathrm{b}}$ ).

The ability of Salmonella to survive in low water activity foods raises specific issues of food safety; it is indicated that $3 \mathrm{CFU} / \mathrm{g}$ may be sufficient to cause illness when consumed in low $a_{w}$ foods (Scheil et al. 1998). The $a_{w}$ of peanut butter ranges from 0.18-0.24. Mattick et. al $\left(2000^{a}\right)$ studied the effect of temperature $\left(55^{\circ}\right.$ to $\left.80^{\circ} \mathrm{C}\right)$ and $\mathrm{a}_{\mathrm{w}}$ (measured by relative vapor pressure 0.65 to 0.90$)$ on the survival of Salmonella. The Weibull model $\left(\operatorname{logs}=-\mathrm{bt}^{\mathrm{n}}\right)$ was used to describe microbial inactivation, and surface presence models were developed to predict death rates for serovar Typhimurium. Cells suspended at low $\mathrm{a}_{\mathrm{w}}$ and treated with temperatures $\geq 70^{\circ} \mathrm{C}$ were more heat tolerant than cells suspended at a higher $\mathrm{a}_{\mathrm{w}}$; however, below $65^{\circ} \mathrm{C}$, the reverse was true. Predicted inactivation of Salmonella in peanut butter $\left(65^{\circ}\right.$ and $\left.74^{\circ} \mathrm{C}\right)$ was more rapid than what was actually observed in the other foods studied. At high temperatures, low $\mathrm{a}_{\mathrm{w}}$ protected the cell against thermal death with a longer time to obtain a $3-\log _{10}$ reduction. The 
temperature dependent effects of low $\mathrm{a}_{\mathrm{w}}$ on heat tolerance of Salmonella reflects different targets for death at low temperatures than at high temperatures (Mattick et al. 2001).

\section{Irradiation}

Irradiation in food is a process by which food products are exposed to ionizing radiation in order to destroy microorganisms, bacteria, viruses, or insects that might be present. Irradiation will reduce the number of probable microbiological hazards that could be present in or on a food or food product. The food or food product remains potentially unaffected in texture, taste, and nutritional value. It has been approved by the Food and Drug Administration for use on meat, poultry, spices, fresh fruits, and vegetables. The safety of irradiated foods has been well studied for many years and no documented adverse health effects have been seen (Urbain 1986).

The energy source in irradiation can be either gamma rays or electron beam. In irradiation, the dose is measured in a unit called a Gray. A Gray measures the amount of energy being used. The death rate of microbes being irradiated is measured by using D-values. Dvalues represent the amount of irradiation needed to eliminate $90 \%$ of a pathogen. D-values help researchers and food industry workers identify the correct dosage needed to administer in a given irradiated food or food product. The dosage of a given food or food product may vary in conjunction with finding the right D-value for a given microorganism and food or food product.

Irradiation works to eliminate organisms by moving energy waves through the molecular bonds in the DNA of an organism. The energy creates reactions that damage the DNA in the microorganism and cause water radiolysis. This in turn, causes problems in genetic instruction, and a dissociation of water molecules. Once this happens the organisms are unable to reproduce. If the organism tries to reproduce or grow it will die (Urbain 1986). 


\section{Current Studies Using E-beam}

Alvarez et al. (2007) studied the effects of modeling irradiation followed by heat inactivation for Salmonella inoculated in liquid whole egg. They focused on Salmonella Typhimurium and Salmonella Senftenberg in liquid whole egg. The authors examined irradiation in correlation with heat treatment as a way to model D-values. They did find significant $5-\log _{10}$ reductions in Salmonella Typhimurium and Salmonella Senftenberg with no differences in nonselective (tryptic soy agar; TSA) versus selective (tryptic soy agar amended with $3 \% \mathrm{NaCl}$; TSASC). This process allowed the authors to specify a direct irradiation dose followed by heat treatments at a set temperature and time to receive a $90 \%$ reduction of viable cells (Alvarez et al. 2007). This approach helps demonstrate the fact that irradiation is successful in reducing the number of viable Salmonella cells in the food product. It also shows the importance of implementing a process that focuses on more than just one process to implement the safest product possible. They found that cell injury occurred following equivalent irradiation and heat treatments. This process was more effective with respect to the corresponding heat treatments, to any temperature and irradiation dose, applied to inactivate the Salmonella. Cell injury following both treatments could reduce the process standard to inactive $5 \log _{10}$ population of Salmonella. Irradiation with heat treatment showed a reduction in the heat treatment intensities. This may, in turn, also reduce the impact of the heat treatment on the freshness and quality of the product.

\section{Conclusion}

Salmonella proves to be a unique microorganism. It has the ability to adapt and survive in low water activity foods for long periods of time. The exact mechanism by which it is able to survive is still unknown. It is known that the way in which it interacts with its environment is 
vital to its survival. Heat tolerance is of main concern in the food industry because without effective processing methods, Salmonella will continue to survive in low water activity, high fat foods such as peanut butter. To have the best protection against food borne pathogens, it is necessary to study them and understand their capabilities. 


\section{References}

Alvarez, I. Niemira, B.A. Fan, X. Sommers, C.H. 2007. Modeling the Irradiation Followed by Heat Inactivation of Salmonella Inoculated in Liquid Whole Egg. Journal of Food Science 72: M145-M152.

Baird-Parker, A.C., Boothryd, M. Jones, E. 1970. The Effect of Water Activity on the Heat Resistance of Heat Sensitive and Heat Resistant Strains of Salmonellae. Journal of Bacteriology 33: 521-522.

Centers for Disease Control and Prevention, 2007. Multistate Outbreak of Salmonella Serotype Tennessee Infections Associated with Peanut Butter-United States, 2006-2007. Morbidity and Mortality Weekly Report 56, 521-525.

Centers for Disease Control and Prevention, 2009. Investigation Update: Outbreak of Salmonella Typhimurium Infections, 2008-2009. http://www.cdc.gov/salmonella/typhimurium/

Food and Drug Administration Center for Food Safety and Applied Nutrition http://vm.cfsan.fda.gov February 2009.

Kieboom, J. Kusumaningrum, H.D. Tempelaars, M.H. Hazeleger, W.C. Abee, T. Beumer, R.R. 2006. Survival, elongation, and elevated tolerance of Salmonella enteric serovar enteritidis at reduced water activity. Journal of Food Protection 69: 26810-2686.

Kirby, R.M. Davies, R. 1990. Survival of Dehydrated Cells of Salmonella Typhimurium LT2 at High Temperatures. Journal of Applied Bacteriology 68:241-246.

${ }^{a}$ Mattick, K.L. Jorgensen, F. Legan, J.D. Lappin-Scott, H.M. Humphrey, T.J. 2000. Habituation of Salmonella spp. at Reduced Water Activity and Its Effect on Heat Tolerance. Applied and Environmental Microbiology 66: 4921-4925.

${ }^{b}$ Mattick, K.L. Jorgensen, F. Legan, J.D. Cole, M.B. Porter, J. Lappin-Scott, H.M. Humphrey, T.J. 2000. Survival and Filamentation of Salmonella enterica Serovar Enteritidis PT4 and Salmonella enteric Servovar Typhimurium DT104 at Low Water Activity. Applied and Environmental Microbiology 66: 1274-1279.

Mattick, K.L. Jorgensen, F. Wang, P. Pound, J. Vandeven, M.H. Ward, L.R Legan, J.D. LappinScott, H.M. Humphrey, T.J. 2001. Effect of Challenge Temperature and Solute Type on Heat Tolerance of Salmonella Serovars at Low Water Activity. Applied and Environmental Microbiology 67: 4128-4136.

Ngwai, Y.B. Wambebe, C. Adachi, Y. 2007. Survivability of Salmonella Typhimurium L1388 and Salmonella enteritidis L1225 under stressful growth conditions. Journal of Health and Allied Sciences. 6: 1-10.

Rubin, R.H. Weinstein, L. 1977. Salmonellosis: Microbiologic, Pathologic and Clinical Features. Stratton Intercontinental Medical Book Corp, New York. 
Shachar D, Yaron S, 2006. Heat Tolerance of Salmonella enteric Serovars Agona, Enteritidis, and Thyphimurium in Peanut Butter. Journal of Food Protection 69:2687-2691.

Scheil, W., W. Cameron, C. Dalton, C. Murray, and D. Wilson. 1998. A South Australian Salmonella Mbandaka Outbreak Investigation Using a Database to Select controls. Australia New Zealand Journal of Public Health 22:536-539.

Urbain, W.M. 1986. Food Irradiation. Orlando Florida: Academic press. P. 351. 


\title{
CHAPTER 3
}

Use of Electron Beam Irradiation for the Reduction of Salmonella enterica Serovars Typhimurium and Tennessee in Peanut Butter

A.L. Hvizdzak, S. Beamer, J. Jaczynski and K.E. Matak

\begin{abstract}
Affiliation:
Division of Animal and Nutritional Sciences, West Virginia University, P.O. Box 6108,

Morgantown, WV 26508
\end{abstract}




\begin{abstract}
Peanut butter and peanut paste products were implicated as the vehicle of contamination in an outbreak of Salmonella Typhimurium that began in September 2008 and in the November 2006 outbreak of Salmonella Tennessee. Therefore, this study evaluated the effectiveness of non-thermal electron beam irradiation for the reduction of Salmonella serovars Tennessee (ATCC 10722) and Typhimurium (ATCC 14028) in creamy peanut butter. Each strain was studied independently. Peanut butter samples were inoculated with approximately $7.0 \log \mathrm{CFU} / \mathrm{g}$ of Salmonella and exposed to e-beam doses ranging from 0-3.1 kGy. Doses were confirmed using film dosimetry. Survivors were enumerated by standard spread-plating on non-selective (tryptic soy agar; TSA) and selective (xylose lysine desoxycholate agar; XLD) media. Microbial counts $(\mathrm{CFU} / \mathrm{g})$ were log-converted and the slopes of the respective survivor curves were determined by linear regression. $\mathrm{D}_{10}$-values were calculated as a negative reciprocal of the slope of the survivor curves and are reported as mean values \pm standard deviation. One-way analysis of variance and Tukey's honestly significant difference test were used to determine differences. $\mathrm{D}_{10}$-values show that Salmonella Typhimurium was more resistant $(0.82 \pm 0.02$ and $0.73 \pm 0.01$ kGy on TSA and XLD, respectively) than Salmonella Tennessee $(0.72 \pm 0.02$ and $0.60 \pm 0.01$ kGy on TSA and XLD, respectively) to e-beam irradiation $(P<0.05)$. The recovery on growth and selective media were different $(P<0.05)$, indicating cell injury. The results of this study demonstrate that e-beam irradiation may be an effective processing step for the non-thermal inactivation of Salmonella in peanut butter.
\end{abstract}




\section{Introduction}

In January 2009 numerous outbreaks of Salmonella serotype Typhimurium were attributed to the consumption of peanut butter, peanut paste, and products made with them. The source of the contamination was traced back to a facility that manufactures peanut products shipped in bulk to hospitals, nursing homes, and schools for use as institutionally-served peanut butter, and to other facilities for use as an ingredient in products such as cookies, cakes, crackers, and ice cream (CDC 2009). Several outbreaks of salmonellosis also emerged in November 2006. The outbreaks of Salmonella serotype Tennessee were associated with the consumption of commercial brands of peanut butter brand; the source of the peanut butter contamination was unknown. While most salmonellosis outbreaks are linked to poultry, meat, eggs, or fresh produce, the incidence of Salmonella in peanut butter proves to be unique because peanut butter provides an environment where organisms are able to survive because of the high fat and low water activity (CDC 2007).

Peanut butter is a semi perishable food, not readily susceptible to spoilage because of its low moisture content. The physical properties of peanut butter make it an unlikely vehicle for foodborne microbial illnesses. Peanut butter is an oil and water emulsion with low water activity $\left(\mathrm{a}_{\mathrm{w}}\right)$. Salmonella cells become more heat tolerant at low $\mathrm{a}_{\mathrm{w}}$, and the effectiveness of heat processing is reduced when Salmonella is present in low $\mathrm{a}_{\mathrm{w}}$ foods (Gill et al. 1983) (Goepfert et al. 1970) (Mattick et al. 2001) (Shachar and Yaron 2006). The high fat content and low $a_{w}$ of peanut butter would likely protect Salmonella against typical peanut butter processing temperatures (Senhaji et al. 1977) (Burnett et al. 2000). 
The manufacturing of peanut butter begins with peanuts harvested from the farm and shipped to a manufacturing facility where they are shelled and cleaned. They are then roasted in ovens at temperatures around $180^{\circ} \mathrm{C}$ for 50 minutes which should be adequate to kill Salmonella (Woodruff 1983). However, since there is no set regulation for the temperature and time in roasting, adequate temperatures or holding times may not be employed. Contamination of peanut butter may also occur after the roasting process (CDC 2007).

When roasting is complete, the peanuts are blanched, ground into a paste, and perhaps mixed with other ingredients such as salt, oil stabilizers and/or sugar. Salmonella can be introduced in the production environment raw peanuts or by other means such as inadequate sanitation, poor plant maintenance during production, and contaminated personnel and/or containers. The target pasteurization temperature prior to packaging is between $70^{\circ}-75^{\circ} \mathrm{C}$; however, Salmonella survives at temperatures as high as $90^{\circ} \mathrm{C}$ (Shachar and Yaron 2006). Salmonella cells demonstrate an increased heat resistance within a high lipid and low $\mathrm{a}_{\mathrm{w}}$ environment (Juneja et al. 2001) (Mattick et al. 2001) (Shachar and Yaron 2006), making this a pathogen of concern for these types of food products. The pasteurization process is ineffective against Salmonella and microbial reductions are not improved by longer treatment (Shachar and Yaron 2006). In fact, higher temperatures and longer exposure times would decrease the quality of the peanut butter by eliciting taste and texture changes (Mattick et al. 2001). The recent Salmonella outbreaks associated with peanut butter and peanut butter products highlight the need for better process controls to ensure product safety.

Electron-beam (e-beam) radiation is a form of ionizing radiation that is generally characterized by its low penetration and high dosage rates. The beam is a concentrated highly charged stream of electrons generated by the acceleration and conversion of electricity. When a 
contaminated food is exposed to e-beam radiation, energy from the electrons is absorbed (absorbed dose) by microbial cells which alter various chemical and biological bonds, destroying their DNA and rendering them unable to reproduce (Cleland 1993). The main assets of this technology include high lethality, fewer detrimental effects on food quality compared to thermal methods, and it does not require the use of radioactive isotopes.

The effectiveness of e-beam irradiation as a non-thermal process for the reduction of pathogenic bacteria in peanut butter has not been reported; therefore, the objective of this research was to investigate the efficacy of e-beam for reduction of Salmonella enterica subsp. enterica serotypes Tennessee and Typhimurium in peanut butter.

\section{Materials and Methods}

\section{Bacterial Cultures}

Salmonella Typhimurium ATCC 14028 and Salmonella Tennessee ATCC 10722 were revived in tryptic soy broth (TSB; unless otherwise stated, all media were from Difco, Becton Dickinson, Sparks, MD), incubated at $37^{\circ} \mathrm{C}$ for $18-24 \mathrm{~h}$ and twice transferred. Working stocks of these cultures were spread onto sterile slants of tryptic soy agar (TSA), incubated at $37^{\circ} \mathrm{C}$ for $18-24 \mathrm{~h}$ and stored at $4^{\circ} \mathrm{C}$.

\section{Inoculum Preparation}

Each strain of Salmonella was twice transferred to $100 \mathrm{ml}$ of TSB (tryptic soy broth) and incubated at $37^{\circ} \mathrm{C}$ for $24 \mathrm{~h}$ in a rotating incubator (Classic C24, New Brunswick Scientific Co., Inc., Edison, NJ, USA) at 150 rpm. Cells were harvested by twice 
centrifugation at 10,000 X G for $10 \mathrm{~min}$ at $5^{\circ} \mathrm{C}$ (Sorvall RC-SB refrigerated super speed centrifuge, Du Pont, Wilmington, DE, USA). After the first centrifugation, the supernatant was poured off. The cells were washed with $100 \mathrm{ml}$ of ddH2O and then re-centrifuged using the same procedure. The remaining pellet was used to inoculate the peanut butter samples.

\section{Peanut Butter Preparation}

A commercially processed creamy peanut butter was purchased at a local grocery store (Morgantown, WV). All equipment used to handle the peanut butter was sanitized by spraying with $70 \%$ ethanol, rinsed with ddH20, and dried under UV light. The inoculums of Salmonella were placed into separate labeled large stomacher bags (Fisherbrand, Hampton, NH, USA) each containing $375 \mathrm{~g}$ of peanut butter. Each bag was inoculated with washed pelleted cells and mixed for one minute to ensure even distribution of the culture. The target initial inoculum level for each strain was $10^{7} \mathrm{CFU} / \mathrm{g}$. The inoculated peanut butter was further divided into $10 \mathrm{~g}$ aliquots, placed into SealPAK bags (Kapak Corp, Minneapolis, MN, USA), and labeled to receive one of six different e-beam radiation doses: 0 (control), $0.5,1,1.5,2$, and $2.5 \mathrm{kGy}$. The sample bags were individually sealed and placed into a larger SealPAK bag to reduce the possibility of leakage or contamination. The peanut butter was spread evenly in the bag to promote even e-beam absorption. The bags were packed in plastic containers (Ziploc 9 1/2 cup container, SC Johnson Products Racine, WI, USA) and stored at $22^{\circ} \mathrm{C}$, (classic C24, New Brunswick Scientific Co., Inc., Edison, NJ USA) until transportation to the irradiation facility. 


\section{Electron Beam Irradiation}

Samples were shipped overnight to an e-beam processing facility (Sterigenics Intl., San Diego, CA, USA). Upon arrival at the irradiation facility, samples were maintained at room temperature $\left(20^{\circ} \mathrm{C}-24^{\circ} \mathrm{C}\right)$. The samples were treated with one sided e-beam with energy fixed at $10 \mathrm{MeV}$. The following target doses were applied: 0 (control), 0.5, 1, 1.5, 2, and $2.5 \mathrm{kGy}$. The actual absorbed dose s were confirmed with film dosimetry. Immediately after e-beam treatment, the samples were repacked and shipped overnight at room temperature. Once back at West Virginia University, samples were placed and stored in an incubator at $22^{\circ} \mathrm{C}$. The total time from inoculation of the samples until commencement of microbial analyses was 6 days (144 hours). Microbial survival over this time was confirmed with no significant reduction in control samples $(\mathrm{P}<0.05)$.

\section{Microbiological Analysis}

Microbial analyses commenced on day 2 after e-beam exposure (day 0). Samples were serially diluted and aliquots of the appropriate dilution were spread-plated in duplicate onto TSA and XLD (xylose, lysine, desoxycholate agar; Remel, Lenexa, KS, USA) agars and incubated for $18-24$ hours at $35^{\circ} \mathrm{C}$. Non-selective media (TSA) was used to facilitate repair of injured cells for comparison of cells recovered on selective media (XLD). Discrete Salmonella colonies were counted.

\section{Statistical Analysis}

The experiment was repeated three separate times. All microbiological analyses were performed in duplicate. Microbial counts (CFU/g) were converted to logarithmic values and analyzed by linear regression using Microsoft Office Excel Software (Office Excel 2007, 
Microsoft Corporation). Tukey's Honestly Significant Differences Test was used to determine significance between the survival rates on (TSA vs. XLD). The recovered cells were expressed as $\log _{10} \mathrm{CFU} / \mathrm{g}$. The $\mathrm{D}_{10}$ value was calculated using the following equation: $\log (\mathrm{N} / \mathrm{No})=-$ $1 / \mathrm{D}^{*} \mathrm{t}$; where $\mathrm{N}=$ number of survivors at e-beam dose, $\mathrm{No}=$ initial microbial concentration, $\mathrm{D}=\mathrm{D}_{10^{-}}$value (decimal reduction dose); and $\mathrm{t}=$ radiation dose (Jaczynski and Park 2003). Survival rates for each dose were analyzed by Tukey's Honestly Significant Differences Test $(\mathrm{P}<0.05)$. The recovered cells were expressed as $\log _{10} \mathrm{CFU} / \mathrm{g}$.

\section{Results and Discussion}

The average recovery of Salmonella Typhimurium and Salmonella Tennessee in creamy peanut butter subjected to e-beam radiation are represented in Table 1. Salmonella Tennessee was more susceptible to e-beam radiation with a 4.9 and $6.66 \mathrm{log}$ reduction of cells on TSA and XLD, respectively, at target e-beam dose of $2.5 \mathrm{kGy}$. Salmonella Typhimurium was reduced by 4.14 and 4.89 logs on TSA and XLD respectively at target e-beam dose of $2.5 \mathrm{kGy}$. Microbial reductions were related to e-beam, as the e-beam dose increased, there was a reduction in the amount of recovered Salmonella cells. Significant microbial reductions were seen after exposure to $0.5 \mathrm{kGy}$ e-beam dose $(\mathrm{P}<0.05)$. Further significant reductions occurred with increasing ebeam doses $(\mathrm{P}<0.05)$. Survivor curves were calculated using actual applied e-beam doses, confirmed using film dosimetry, and $\mathrm{D}_{10}$-values (Table 2) were calculated from the respective survivor curves (Figures 1 and 2). $\mathrm{D}_{10}$-values show that Salmonella Typhimurium was more resistant ( $0.82 \pm 0.02$ and $0.73 \pm 0.01 \mathrm{kGy}$ on TSA and XLD, respectively) than Salmonella Tennessee $(0.72 \pm 0.02$ and $0.60 \pm 0.01 \mathrm{kGy}$ on TSA and XLD, respectively) to e-beam 
irradiation $(P<0.05)$. A greater than 5 -log reduction was achieved after $3.0 \mathrm{kGy}$ dose when cells were recovered on TSA media; a greater than 6 -log reduction was attained when recovery was on selective XLD media. The greatest significant microbial reductions in Salmonella were seen at the target dose of $2.5 \mathrm{kGy}$ e-beam radiation $(\mathrm{P}<0.05)$. The recovery on growth and selective media were different $(P<0.05)$, indicating cell injury.

E-beam treatment was effective in reducing the overall number of Salmonella survivors. While reductions were seen from $1 \mathrm{kGy}$ to $3.1 \mathrm{kGy}$, the most significant $(\mathrm{P}<0.0 .5)$ reduction in survivors was seen at e-beam dose of 2.7-3.1 kGy. Salmonella Typhimurium was more resistant to e-beam treatment compared to Salmonella Tennessee $(\mathrm{P}<0.05)$. One study by Sherry et. al. (2008) looked at the response of forty different Salmonella species to different doses of irradiation in order to identify the Salmonella species that are most likely to be radiation resistant. They examined the correlation between surviving cell counts and the recovery time of Salmonella at $1.5 \mathrm{kGy}$ at $20^{\circ} \mathrm{C}$. After the stresses of irradiation, heat, or high hydrostatic pressure were applied to Salmonella, the time taken to recover and grow to a defined activity level was calculated. The time taken was referred to as the TTD (Time to Detection) while the TVC (Total Viable Counts) was recorded in $\log _{10} \mathrm{CFU} / \mathrm{ml}$. High numbers of survivors would be seen in resistant isolates and would result in a shorter TTD; in conjunction a longer TTD would be seen by a sensitive isolate. There was a significant correlation between the TVC and TTD $(\mathrm{P}<0.01)$, of irradiated Salmonella species. The TTD was inversely proportional to the TVC $(\mathrm{P}<0.01)$ (Sherry et al. 2008). After comparison to heat and high hydrostatic pressure Sherry and others (2008) determined that irradiation stresses left less cell injury. They attribute their findings to the low incubation time of 9 hours and the low dosage $(1.5 \mathrm{kGy})$ of irradiation. They 
did not report differences between each species of Salmonella, but noted that differences were seen between species.

The D-values of Salmonella in peanut butter were greater than those reported for other pathogens in higher $\mathrm{a}_{\mathrm{w}}$ foods. The D-value of E.coli 0157:H7 subjected to e-beam irradiation at room temperature beef patties was $0.22 \mathrm{kGy}$ (Black and Jaczynski 2006). Similar results were presented by Rochelle et al (1994) and Thayer and Boyd (2001) respectively. The differences in fat content of the beef patties influenced the effectiveness of e-beam to reduce microbial load. This may partly explain the greater D-values for Salmonella in peanut butter. Peanut butter shows a much higher resistance to irradiation compared to that of beef, chicken, or trout. Peanut butter has a much higher fat content and lower $\mathrm{a}_{\mathrm{w}}$ which would contribute to the greater Dvalues.

The effect of $\gamma$-radiation on bacterial reductions in butter showed that bacterial counts were reduced by $75 \%$ and $98.9 \%$ with the application of irradiation at 2.5 and $5 \mathrm{kGy}$ dose. Dvalues were not reported (Rady and Badr 2003). Butter, like peanut butter, is an oil and water emulsion with a high fat content; butter has greater $\mathrm{a}_{\mathrm{w}}$ than peanut butter. The difference in water activity may account for differences seen in microbial reductions in peanut butter. Differences are also likely to be attributed to the diversity of the microorganisms used (Rady and Badr 2003).

When microbes are present in the food being irradiated, the energy from the rays is transferred to the water and other molecules in the microbe. The energy damages the DNA in the microbe, causing defects in the genetic instructions. Unless it can repair this damage, the microbe will die when it grows and tries to duplicate itself (Urbain 1986). The microorganisms 
are unable to multiply, thus, reproductive death is achieved. Water subjected to ionizing radiation undergoes a radiolysis reaction, in which free radicals are generated. This is considered an indirect mechanism of microbial inactivation because when the ionized radiation is applied, the radiolysed water molecules disintegrate the microbial cells (Urbain 1986). It is therefore believed that the most important contributor to the antimicrobial effect of e-beam by indirect mechanism is the physical state of water. Peanut butter has low $\mathrm{a}_{\mathrm{w}}$ which may provide protection to Salmonella against damage by free radicals.

Two distinct characteristics make peanut butter a unique system; its high fat content and its colloidal suspension of lipid and water. The combination of both, high fat and low water in foods such as peanut butter might have a synergistic effect. Mattick et al. $\left(2000^{\mathrm{a}}\right)$ found that although death of Salmonella in low $\mathrm{a}_{\mathrm{w}}$ foods occurred at the rate predicted by their thermal inactivation models, Salmonella actually survived in peanut butter for a much longer amount of time. This demonstrates the limits of using a predictive modeling for peanut butter perhaps because of its relatively neutral $\mathrm{pH}$ and high fat content They believe that $\mathrm{pH}$ is an important factor influencing the survival of Salmonella at low $a_{w}$ when exposed to heat (Mattick $2000^{\mathrm{a}}$ ). The $\mathrm{pH}$ of a food is an important factor in the way in which a foodborne pathogen can survive. A study by Ngwai et al. (2007) studied the effects of Salmonella Typhimurium and Salmonella enteritidis in different $\mathrm{pH}$ levels. They found both Salmonella species to have more growth at a $\mathrm{pH}$ of 4 compared to a $\mathrm{pH}$ of $2.6(\mathrm{P}<0.05)$. There were no differences between species $(\mathrm{P}<0.05)$. The $\mathrm{pH}$ of 4 and 2.6 were chosen to represent what would typically be seen in the human stomach. The data presented shows that Salmonella is easily able to survive the gastric juices of the stomach (Ngwai et al. 2007). Peanut butter has a pH of approximately 6.3. It is not acidic, but Salmonella may have more resistance and better motility at a less acidic $\mathrm{pH}$. Eggs also have 
a pH of approximately 6.5 and are commonly associated with Salmonella pathogens. It is known that microbes are most resistant to heat at an optimum $\mathrm{pH}$; this may also hold true for irradiation (Nwagi et al. 2007). This demonstrates the importance of $\mathrm{pH}$ as a factor in bacterial growth.

E-beam irradiation shows positive effects for the reduction of Salmonella spp. in peanut butter. All levels of e-beam irradiation reduced initial microbial counts. Future studies to investigate survival and growth characteristics of e-beamed Salmonella spp. in various commercial brands of peanut butter and peanut butter products need to be done in order to better understand the specific environment, quality, and safety of irradiation in peanut butter. 


\section{References}

Black, J.L. Jaczynski, J. 2006. Temperature Effect on Inactivation Kinetics of Escherichia coli 0157:H7 by Electron Beam in Ground Beef, Chicken Breast Meat, and Trout Fillets. Journal of Food Science 71:M221-M227.

Burnett, S. L Gehm, E.R Weissinger, W.R. Bechat, L.R. 2000. Survival of Salmonella in peanut butter and peanut butter spread. Journal of Applied Microbiology 89:472-477.

Centers for Disease Control and Prevention, 2007. Multistate Outbreak of Salmonella Serotype Tennessee Infections Associated with Peanut Butter-United States, 2006-2007. Morbidity and Mortality Weekly Report 56, 521-525.

Centers for Disease Control and Prevention, 2009. Investigation Update: Outbreak of Salmonella Typhimurium Infections, 2008-2009. http://www.cdc.gov/salmonella/typhimurium/

Cleland, M. R. O’Neill, Melanie, T. Thomposon, C.C. 1993. "Sterilization with Accelerated Electrons" Sterilization Technology a Practical Guide for Manufactures and Users of Health Care Products Van Nostrand Reinhold, New York.

Gill, O. N. Sockett, P. N. Bartlett, C. L. R. Vaile, M. S. B. 1983. Outbreak of Salmonella napoli infection caused by contaminated chocolate bars. Lancet. 574-577.

Goepfert, J. M. Iskander, I. K. Amundson, C. H. 1970. Relation of the heat resistance of salmonellae to the water activity of the environment. Appl Microbiol. 19: 429-433.

Jaczynski, J. Park, J. W. 2003. Microbial inactivation and electron penetration in surimi seafood during electron beam processing. Journal of Food Science 68: 1778-1792.

Juneja VK, Eblem BS, marks HM. 2001. Modeling Nonlinear Survival Curves to Calculate Thermal Inactivation of Salmonella in Poultry of Different Fat Levels. International Journal of Food Microbiology 70: 37-51.

Mattick, K.L. Jorgensen, F. Legan, J.D. Lappin-Scott, H.M. Humphrey, T.J. 2000. Habituation of Salmonella spp. at Reduced Water Activity and Its Effect on Heat Tolerance. Applied and Environmental Microbiology 66: 4921-4925.

Mattick, K.L. Jorgensen, F. Wang, P. Pound, J. Vandeven, M.H. Ward, L.R Legan, J.D. LappinScott, H.M. Humphrey, T.J. 2001. Effect of Challenge Temperature and Solute Type on Heat Tolerance of Salmonella Serovars at Low Water Activity. Applied and Environmental Microbiology 67: 4128-4136.

Ngwai, Y.B. Wambebe, C. Adachi, Y. 2007. Survivability of Salmonella Typhimurium L1388 and Salmonella enteritidis L1225 under stressful growth conditions. Journal of Health and Allied Sciences. 6: 1-10. 
Rady, A.H. Badr, H.M. 2003. Keeping the Quality of Cows' Butter by $\gamma$-Irradiation. Fats and Oils 54: 410-418.

Rochelle, S. Clavero, J. Monk, J.D. Beuchat, L.R. Doyle, M.P. Brackett, R.E. 1994. Inactivation of Escherichia coli 0157:H7, Salmonellae, and Campylobacter jejuni in raw ground beef by gamma irradiation. Applied Environmental Microbiology 59:1030-1034.

Senhaji, A. F. 1977. The protective effect of fat on the heat resistance of bacteria. Journal of Food Technology 12: 203-216.

Shachar D, Yaron S, 2006. Heat Tolerance of Salmonella enteric Serovars Agona, Enteritidis, and Thyphimurium in Peanut Butter. Journal of Food Protection 69:2687-2691.

Sherry, A.E. Patterson, M.F. Madden, R.H. 2008. Use of conductimetry to rapidly determine relative stress sensitivity in Salmonella isolates. Journal of Applied Microbiology. 106: 675-681.

Thayer, D.W. Boyd, G. 2001. Effect of irradiation temperature on inactivation of Escherichia coli 0157:H7 and Staphylococcus aureus. Journal of Food Protection 64:1624-1626.

Urbain, W.M. 1986. Food Irradiation. Orlando Florida: Academic press. P. 351.

Woodroof, J.G. 1983. Peanut butter In: Peanuts: Production, Processing, Products, $3^{\text {rd }}$ ed. Westport, Conn: VI Publishing Company Inc. p. 181-227. 
Table 1. Survival of Salmonella Tennessee and Salmonella Typhimurium (mean log CFU/g \pm $\mathrm{SD} ; \mathrm{n}=6$ ) in peanut butter plated on non-selective tryptic soy agar (TSA) and selective xylose lysine deoxycholate agar (XLD).

\begin{tabular}{|c|c|c|c|c|}
\hline \multirow{3}{*}{$\begin{array}{c}\text { Target } \\
\text { E-beam dose } \\
(\mathrm{kGy})\end{array}$} & \multicolumn{4}{|c|}{ Mean Survivors (log CFU/g) } \\
\hline & \multicolumn{2}{|c|}{ Salmonella Tennessee } & \multicolumn{2}{|c|}{ Salmonella Tyhpimurium } \\
\hline & TSA & XLD & TSA & XLD \\
\hline 0 & $8.20 \pm 0.09^{\mathrm{a}}$ & $8.20 \pm 0.09^{\mathrm{a}}$ & $8.32 \pm 0.12^{\mathrm{a}}$ & $8.25 \pm 0.14^{\mathrm{a}}$ \\
\hline 0.5 & $5.43 \pm 0.05^{\mathrm{b}}$ & $4.30 \pm 0.11^{\mathrm{b}}$ & $5.41 \pm 0.03^{b}$ & $5.32 \pm 0.16^{\mathrm{b}}$ \\
\hline 1 & $4.26 \pm 0.16^{\mathrm{c}, \mathrm{d}}$ & $4.19 \pm 0.11^{b}$ & $5.35 \pm 0.16^{\mathrm{b}}$ & $4.77 \pm 0.17^{\mathrm{c}}$ \\
\hline 1.5 & $4.46 \pm 0.08^{\mathrm{c}}$ & $4.32 \pm 0.11^{\mathrm{b}}$ & $4.49 \pm 0.15^{\mathrm{c}}$ & $4.42 \pm 0.07^{\mathrm{c}}$ \\
\hline 2 & $3.84 \pm 0.28^{\mathrm{d}}$ & $3.55 \pm 0.18^{\mathrm{c}}$ & $4.04 \pm 0.29^{c}$ & $3.90 \pm 0.32^{\mathrm{d}}$ \\
\hline 2.5 & $3.30 \pm 0.16^{\mathrm{e}}$ & $1.54 \pm 0.15^{\mathrm{d}}$ & $4.18 \pm 0.09^{c}$ & $3.43 \pm 0.10^{\mathrm{d}}$ \\
\hline
\end{tabular}

a,b,c,d,e Values designated with the same letter within a column are not significantly different 
Table 2. $\mathrm{D}_{10}$-values of Salmonella serotypes Tennessee and Typhimurium in peanut butter exposed to e-beam irradiation.

\begin{tabular}{lcc}
\hline & D $_{10}$-Value & \\
\hline Salmonella serotype & TSA & XLD \\
\hline Tennessee & $0.72 \pm 0.02^{1, \mathrm{a}}$ & $0.60 \pm 0.01^{2, \mathrm{a}}$ \\
Typhimurium & $0.82 \pm 0.02^{1, \mathrm{~b}}$ & $0.73 \pm 0.01^{2, \mathrm{~b}}$ \\
\hline
\end{tabular}

${ }^{1,2}$ Values with different superscript numbers within rows indicate significant differences in recovery on selective verses non-selective media $(P \leq 0.05)$.

${ }^{\mathrm{a}, \mathrm{b}}$ Values with different superscript lowercase letters within columns indicate significant differences in recovery between the two Salmonella serotypes $(P \leq 0.05)$. 
Figure 1. Survivor curve for Salmonella Tennessee in peanut butter subjected to electron beam on TSA and XLD.

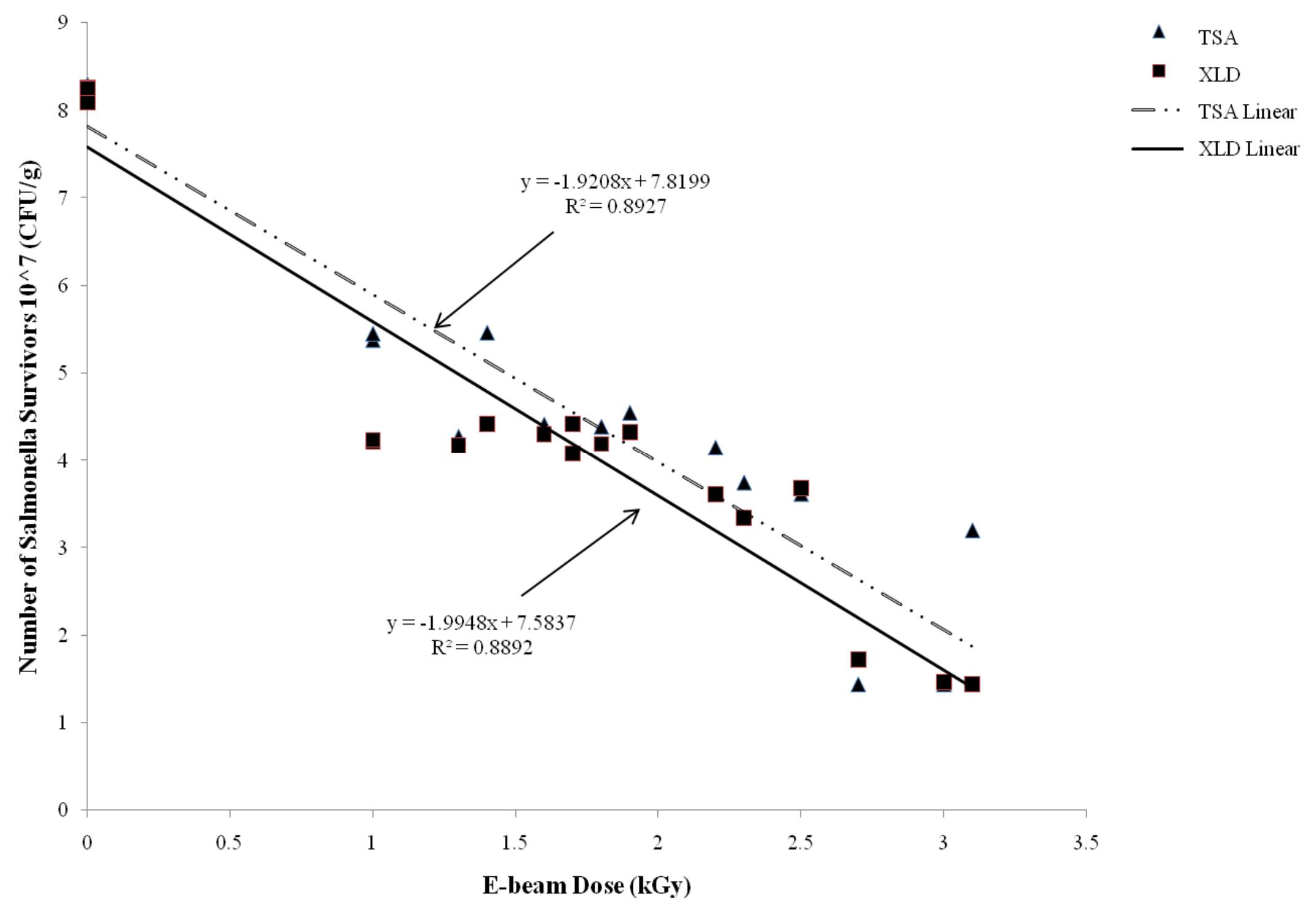


Figure 2. Survivor curve for Salmonella Typhimurium in peanut butter subjected to electron beam on TSA and XLD.

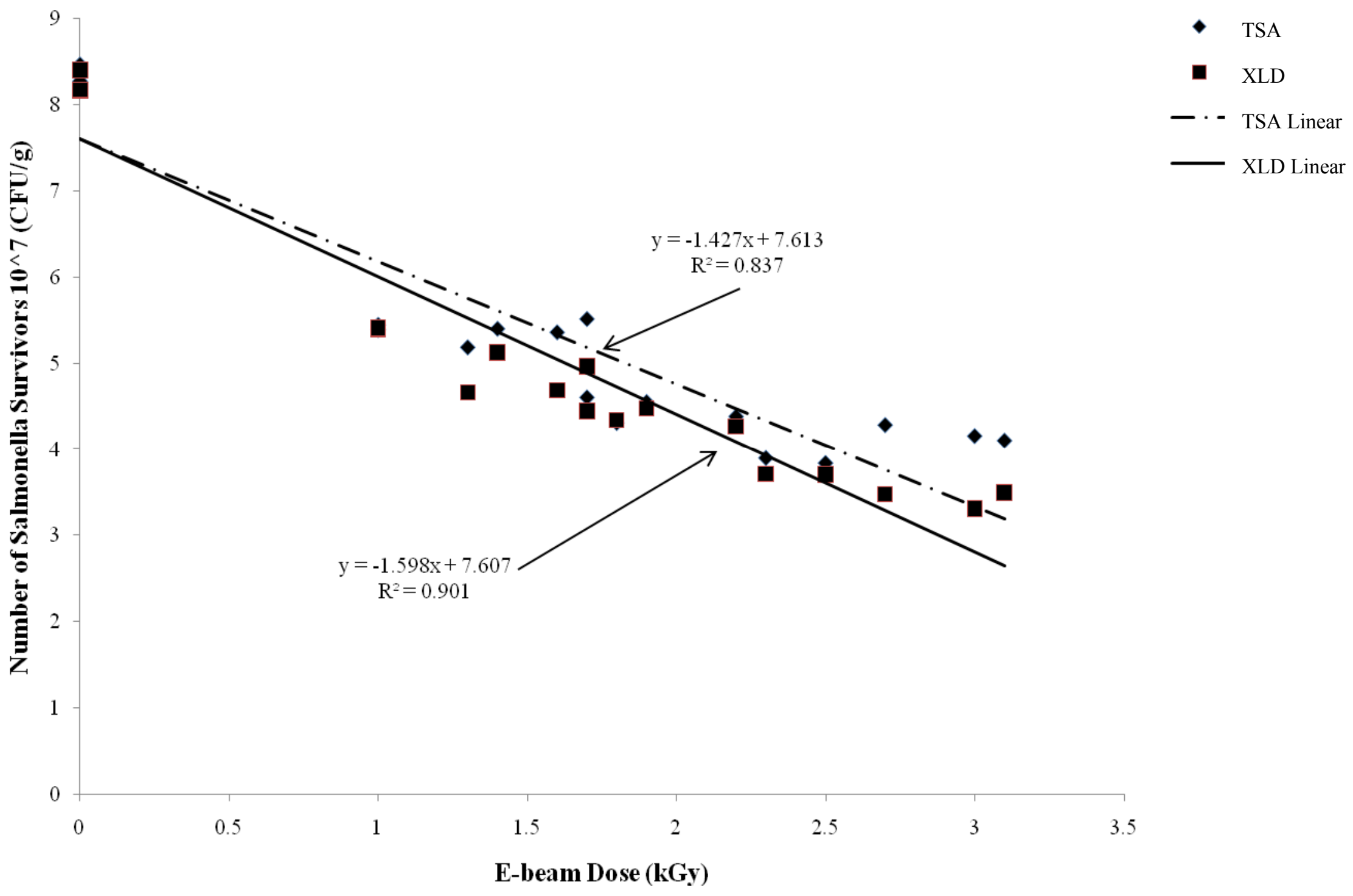




\section{CHAPTER 4}

Fate of Salmonella enterica Serovars Typhimurium and Tennessee in Peanut Butter after Electron Beam Exposure

A.L. Hvizdzak, S. Beamer J. Jaczynski, and K.E. Matak

Affiliation:

Division of Animal and Nutritional Sciences, West Virginia University, P.O. Box 6108,

Morgantown, WV 26508 


\begin{abstract}
The purpose of this study was to determine the effect of electron beam irradiation on the survival of Salmonella serotypes Tennessee (ATCC 10722) and Typhimurium (ATCC 14028) in creamy peanut butter over a $14 \mathrm{~d}$ storage period at room temperature $\left(22^{\circ} \mathrm{C}\right)$. Each Salmonella type was independently inoculated into peanut butter and subjected to the following e-beam doses: 0 (control), $0.5,1,1.5,2$, and $2.5 \mathrm{kGy}$, which were confirmed using film dosimetry. After 2, 4, 6, 8, and $14 \mathrm{~d}$ of storage, microbial analyses were conducted. Survivors were enumerated on growth (tryptic soy agar; TSA) and selective (xylose lysine deoxycholate: XLD) media using a standard spread-plating method. Microbial counts (CFU/g) were log converted and differences were determined using one-way analysis of variance and Tukey's honestly significant difference test. The rate of microbial decline was significant over the $14 \mathrm{~d}$ storage period $(P<0.05)$. The greatest reductions were seen at target e-beam dose $2.5 \mathrm{kGy}$ at day 14 $(P<0.05)$. Salmonella Tennessee was not recovered at target dose $2.5 \mathrm{kGy}$ in either growth (TSA) or selective (XLD) media $(<10 \mathrm{CFU} / \mathrm{g})$. Salmonella Typhimurium had the fewest mean survivors at the target $2.5 \mathrm{kGy}$ dose with $2.12 \pm 0.37 \log \mathrm{CFU} / \mathrm{g}$ recovered on TSA and no recovery on XLD $(<10 \mathrm{CFU} / \mathrm{g})$. The recovery of cells on growth and selective media were different $(\mathrm{P}<0.05)$, indicating cell injury. Microbial reductions were related to e-beam dose, as the e-beam dose increased, there was a significant reduction in the amount of recovered Salmonella cells. The results of this study indicate that Salmonella Tennessee and Salmonella Typhimurium exposed to e-beam irradiation in peanut butter will decline overtime.
\end{abstract}




\section{Introduction}

In February 2009 the Center of Disease Control (CDC) collaborated with public health officials and the United States Food and Drug Administration (FDA) to investigate a multistate outbreak of human infections due to Salmonella serotype Typhimurium. The infections were related to peanut butter and peanut butter paste products, and as of March 2009 potentially contaminated products were still being recalled (CDC 2009). In November 2006, Salmonella Tennessee was the infectious agent in a multistate outbreak related to the consumption of peanut butter. The source of the Salmonella is still under investigation. The ability of Salmonella to survive in peanut butter and peanut butter products over a period of time is one of the CDC's main concerns (CDC 2007).

Salmonella can be introduced into peanut butter manufacturing through a number of different processes including: cleaning, peeling, roasting, cooling, and packaging. The source of the Salmonella can come from a wide variety of possible sources such as: unsanitary workers, contaminated/unsanitary equipment, or environmental sources. Once Salmonella is introduced into a low water activity $\left(\mathrm{a}_{\mathrm{w}}\right)$ food it has the ability to survive for long periods of time; likely due to an adaptive stress response. For example, filamentation occurs in Salmonella cells as a result of the exposure to a low $\mathrm{a}_{\mathrm{w}}$ over time (Mattick et al. $2000^{\mathrm{a}}$ ) (Kieboom et al. 2006). Filamentation is an abnormal growth that occurs within bacteria in response to stress where DNA replication continues and the cells elongate, but they do not divide. When conditions become more favorable, like with an increase in $\mathrm{a}_{\mathrm{w}}$, rapid division of viable Salmonella cells resume (Mattick et al. $2000^{\mathrm{b}}$ ). Salmonella cells that exhibit filamentation are able to maintain their membrane integrity for up to 21 days (Kieboom et al. 2006). These changes will make the cells more resistant to disinfection measures like exposure to hypochlorite solutions, highlighting the 
importance of proper cleaning and disinfection procedures in the processing environment (Kieboom et al. 2006). Peanut butter is a low water activity food and for that reason gives Salmonella an optimal environment for growth. This poses to be a risk factor for public health because the filaments of the Salmonella cells are able to survive for long periods of time.

Salmonella are more resistant to heat at low $\mathrm{a}_{\mathrm{w}}$. The $\mathrm{a}_{\mathrm{w}}$ of peanut butter is between $(0.22$ -0.29 ) and is considered a low $a_{w}$ food. Peanut butter undergoes a typical heat pasteurization process at $>70^{\circ} \mathrm{C}$. Mattick et al. (2001) showed that low $\mathrm{a}_{\mathrm{w}}$ had a protective effect on Salmonella cells exposed to temperatures $\geq 70^{\circ} \mathrm{C}$. Cells are more tolerant to heat when suspended in low $\mathrm{a}_{\mathrm{w}}$ environments; therefore, the heat treatment for peanut butter may not be effective for reducing the amount of viable Salmonella cells in peanut butter. Researchers argue whether it is the change in structure of the Salmonella species, or whether it is the ability of Salmonella to adapt that makes it more resistant to certain stresses including heat. Mattick and others (2001) studied the effects on heat tolerance at a reduced water activity state. They found that the Salmonella was able to adapt through habituation; however, this was not demonstrated by de novo protein synthesis or RpoS expression (Mattick et al. $2000{ }^{\mathrm{a}}$ ). Recall that RpoS controls the expression of genes that respond to environmental stresses such as heat shock and osmotic stress. The ability of viable Salmonella cells to conform to their environment may have been due to the modification of existing cell proteins (Mattick et al. 2000 a). Mattick et al. (2001) identified that at temperatures $>70^{\circ} \mathrm{C}$, Salmonella was more heat tolerant at low $\mathrm{a}_{\mathrm{w}}$ than at higher $\mathrm{a}_{\mathrm{w}}$. Researchers need to come up with a reliable method of eliminating Salmonella in low $\mathrm{a}_{\mathrm{w}}$ foods. This leaves many government agencies and public health officials searching for new methods and processes that may alleviate the unsafe practices now implied. 
A new area of research in food safety is irradiation. Certain foods or food products are exposed to ionizing radiation in order to destroy microorganisms, bacteria, viruses, or insects that might be present. Irradiation has the ability to reduce the number of probable microbiological hazards that could be present in or on a food or food product. Many food and food products tested remain potentially unaffected in texture, taste, and nutritional value. This process has already been implemented in the food industry for products like poultry, meat, spices, fresh fruit and vegetables. Irradiation has been shown to be effective in its ability to reduce Salmonella species in these products. This has been demonstrated in multiple studies. A study by Sarjeant et al. (2005) showed a 4-log reduction in microbial counts of commercial chicken breasts treated with 1, 2, and $3 \mathrm{kGy}$ of irradiation (Sarjeant et al. 2005). Another study by Lewis and others (2002) found boneless skinless chicken breasts free of Salmonella after being treated with ebeam irradiation doses of 1.0 and $1.8 \mathrm{kGy}$ (Lewis et al. 2002). Its ability to be effective in low water activity high fat foods like peanut butter has not yet been studied.

To date there have been no studies that have examined the survival of Salmonella species in low $\mathrm{a}_{\mathrm{w}}$ foods over time after being treated with doses of e-beam irradiation. The objective of this study was to observe the survival characteristics of Salmonella enterica subspecies enterica serotypes Tennessee and Typhimurium in e-beam irradiated peanut butter over a two week shelf life at $22^{\circ} \mathrm{C}$. 


\section{Materials and Methods}

\section{Bacterial Cultures}

Cultures of Salmonella Typhimurium ATCC 14028 and Salmonella Tennessee ATCC 10722 were revived in tryptic soy broth (TSB; unless otherwise stated, all media were from Difco, Becton Dickinson, Sparks, MD), incubated at $37^{\circ} \mathrm{C}$ for $18-24 \mathrm{~h}$ and twice transferred. The working stocks were spread onto sterile slants of tryptic soy agar (TSA), incubated at $37^{\circ} \mathrm{C}$ for $18-24 \mathrm{~h}$ and stored at $4^{\circ} \mathrm{C}$.

\section{Inoculum Preparation}

Salmonella Typhimurium and Salmonella Tennessee were respectively twice transferred into $100 \mathrm{ml} \mathrm{TSB}$ (tryptic soy broth) and incubated at $37^{\circ} \mathrm{C}$ for $24 \mathrm{~h}$ in a rotating incubator (Classic C24, New Brunswick Scientific Co., Inc., Edison, NJ, USA) at 150 rpm. Twice centrifugation at $10,000 \mathrm{X} \mathrm{G}$ for $10 \mathrm{~min}$ at $5^{\circ} \mathrm{C}$ was used to harvest the cells (Sorvall RC-SB refrigerated super speed centrifuge, Du Pont, Wilmington, DE, USA). After centrifugation, the supernatant was poured off. The cells were then washed with $100 \mathrm{ml}$ of ddH2O. After being rinsed, the cells were re-centrifuged using the same procedure. The remaining cells were used to inoculate the peanut butter samples.

\section{Peanut Butter Preparation}

For the samples, regular creamy peanut butter (Peter Pan, ConAgra Foods, Omaha, NE) was used. The peanut butter was purchased at a local grocery store. During the experiment, all equipment was sanitized by spraying with $70 \%$ ethanol, rinsed with ddH 20 , and dried under UV light. The Salmonella inoculums were placed into large stomacher 
bags (Fisherbrand, Hampton, NH, USA) each containing $375 \mathrm{~g}$ of peanut butter. Each bag was labeled and inoculated respectively. The samples were then pummeled by hand to ensure even distribution. $10^{7} \mathrm{CFU} / \mathrm{g}$ was the target inoculum level for each strain. For even treatment distribution purposes, the inoculated peanut butter was further divided into $10 \mathrm{~g}$ aliquots, and placed into 4" $\times 6$ " SealPAK bags (Kapak Corp, Minneapolis, MN, USA). All bags were labeled to receive one of six different e beam radiation doses: 0 (control), $0.5,1,1.5,2$, and $2.5 \mathrm{kGy}$. There were twenty bags per dose to allow for analysis over time. In order to reduce the possibility of leakage or contamination, the sample bags were individually sealed and placed into 6.5 " $\times 8$ " SealPak. The peanut butter was spread out in the bag to promote even e-beam absorption. The samples were packed in plastic containers (Ziploc 9 1⁄2 cup container, SC Johnson Products Racine, WI, USA) according to treatment and stored at $22^{\circ} \mathrm{C}$ (classic C24, New Brunswick Scientific Co., Inc., Edison, NJ USA) until transportation to the irradiation facility.

\section{Electron Beam Irradiation}

Samples were shipped to an e-beam processing facility (Sterigenics Intl., San Diego, CA, USA). Samples were received at the facility overnight and were maintained at room temperature $\left(20^{\circ} \mathrm{C}-24^{\circ} \mathrm{C}\right)$. One-sided e-beam with energy fixed at $10 \mathrm{MeV}$ was used for all the samples. Target doses of: 0 (control), $0.5,1,1.5,2$, and $2.5 \mathrm{kGy}$ were applied. After e beam treatment, the samples were repacked, shipped overnight, and kept at $22^{\circ} \mathrm{C}$. Once received back at West Virginia University, the samples were stored at $22^{\circ} \mathrm{C}$. Total time from inoculation of the samples until beginning of microbial analyses was 6 days (144 hours). Microbial survival over time was confirmed with no significant reduction in control samples $(\mathrm{P}<0.05)$. 


\section{Microbiological Analysis}

Microbial analyses started on day 2 after exposure to e-beam (day 0). Analysis was completed on days $4,6,8$, and 14 to determine microbial reductions over time. Serially diluted samples and aliquots of the dilutions were spread-plated in duplicate onto TSA and XLD (xylose, lysine, deoxycholate agar; Remel, Lenexa, KS, USA) agars. The plates were incubated for $18-24$ hours at $35^{\circ} \mathrm{C}$. Non-selective media (TSA) was used to facilitate repair of injured cells for comparison of cells recovered on selective media (XLD). Isolated Salmonella colonies were counted.

\section{Statistical Analysis}

The experiment was replicated three times, and microbiological analysis was performed in duplicate. Microbial counts (CFU/g) were converted to logarithmic values and analyzed by linear regression using Microsoft Office Excel Software (Office Excel 2007, Microsoft Corporation). The recovered cells were expressed as $\log _{10} \mathrm{CFU} / \mathrm{g}$. The survival rates for each dose and for each day were analyzed by Tukey's Honestly Significant Differences Test $(\mathrm{P}<0.05)$.

\section{Results and Discussion}

The average recovery of Salmonella Typhimurium and Salmonella Tennessee in creamy peanut butter subjected to e-beam radiation over a period of 14 days is represented in Tables 1-4. Recovery of cells on growth and selective media were different $(\mathrm{P}<0.05)$, indicating cell injury. Salmonella Tennessee and Salmonella Typhimurium both had the fewest mean survivors at target e-beam dose $2.5 \mathrm{kGy}$ at day 14 . Salmonella Tennesssee was not recovered at the target ebeam dose $2.5 \mathrm{kGy}$ on either selective (XLD) or non-selective (TSA) media ( $<10 \mathrm{CFU} / \mathrm{g}$ ). 
Salmonella Typhimurium had the fewest mean survivors at the target e-beam dose of $2.5 \mathrm{kGy}$ with $2.12 \pm 0.37 \log$ CFU/g recovered on TSA and no recovery on XLD $(<10 \mathrm{CFU} / \mathrm{g})$. Microbial reductions were related to e-beam dose, as the e-beam dose increased, there was a significant reduction in the amount of recovered Salmonella cells (Figures 1-4). Mean Salmonella survivors also decreased overtime. Significant reductions overtime were not seen until day 8 for Salmonella Typhimurium and day 14 for Salmonella Tennessee when recovered on TSA agar $(\mathrm{P}<0.05)$. Mean Salmonella populations were significantly reduced after exposure to $0.5 \mathrm{kGy}$ ebeam dose, significant reductions occurred with increasing e-beam doses $(\mathrm{P}<0.05)$. Changes in the log number of Salmonella survivors were seen between days, but were only significantly different at day 14 , specifically at target e-beam dose of $2.5 \mathrm{kGy}(\mathrm{P}<0.05)$. At day 14 , a greater than 2-log and 0.5-log reduction was seen in Salmonella Tennessee recovered on TSA and XLD, respectively. A greater than 2-log reduction of Salmonella Typhimurium was seen over time regardless of recovery media. The greatest overall significant microbial reductions in Salmonella were seen at the target dose of $2.5 \mathrm{kGy}$ e-beam radiation overtime $(\mathrm{P}<0.05)$.

Other recent studies on the effects Salmonella in peanut butter over storage time have found similar results. Burnett et al. (2000) found that Salmonella survives in peanut butter and peanut butter spreads for at least 24 weeks. They believe that Salmonella is likely to survive in peanut butters and spreads for the duration of their expected shelf life (Burnett et al. 2000). In our study, Salmonella was able to survive up to two weeks even when significantly injured by ebeam irradiation.

Salmonella viability is affected by the storage temperature in colloidal food products. It is more likely to survive at lower temperatures over higher ones, likely due to their reduction of 
metabolic activity at the lower temperatures (Holliday and Beuchat 2003) (Holliday et al. 2003) (Park et al. 2000). This is consistent with the finding of Park et al. (2000) who looked at the effect of storage time (14 day) and temperature $\left(22^{\circ} \mathrm{C}\right.$ vs. $\left.4^{\circ} \mathrm{C}\right)$ on the fate of Salmonella Tennessee in different commercial brands of peanut butter. They found that Salmonella death was more rapid when stored at $22^{\circ} \mathrm{C}$ compared to $4{ }^{\circ} \mathrm{C}$ for a two week period.

Burnett et al. (2000) reported that the rate of Salmonella survival in peanut butter and peanut butter spread was related to differences in the size and stability of water droplets. Since Salmonella in peanut butter is likely to be found near the water phase, a finer emulsion would create an environment where nutrients are less available (Mattick et al. $2000^{\mathrm{b}}$ ). Of the five commercial brands of peanut butter studied, one brand showed significance $(\mathrm{P}>0.05)$ between selective versus non-selective media, while the other 4 brands showed no significant difference. Despite these differences there were no differences in the composition of the five brands studied (Park et al. 2008). Our results on the survival of Salmonella in peanut butter support the observations of Park and others (2008). Our results indicated that there was no significance $(\mathrm{P}>0.05)$ trends seen between selective $(\mathrm{XLD})$ and non-selective (TSA) media. It demonstrates the ability of Salmonella to survive independently over time despite temperature variations. Our current study showed that under typical storage temperatures at $22^{\circ} \mathrm{C}$, Salmonella will persist even if injured by e-beam irradiation. However, Park and others (2008) showed that Salmonella would likely survive for a much longer period if stored at $4^{\circ} \mathrm{C}$. This highlights the critical need to find a processing treatment that would effectively kill all pathogens of concern.

In our study, all levels of e-beam treatment reduced the initial Salmonella populations. Regardless of dose and species, the microbial counts significantly decreased after 14 days of 
storage time; however, significant reductions were seen sooner (after day 6) in samples treated with greater e-beam doses ( $\geq 2 \mathrm{kGy}$ ). Salmonella would survive over the shelf life of peanut butter even if the cells sustained injury. The results of this study demonstrate the need to reduce the occurrence of post-processing contamination and to find a non-thermal processing method capable of effectively eliminating pathogens from peanut butter. Future research will look at the effect of high beam dose on the functional and sensorial properties of peanut butter. 


\section{References}

Burnett, S. L Gehm, E.R Weissinger, W.R. Bechat, L.R. 2000. Survival of Salmonella in peanut butter and peanut butter spread. Journal of Applied Microbiology 89:472-477.

Centers for Disease Control and Prevention, 2009. Investigation Update: Outbreak of Salmonella Typhimurium Infections, 2008-2009. http://www.cdc.gov/salmonella/typhimurium/

Centers for Disease Control and Prevention, 2007. Multistate Outbreak of Salmonella Serotype Tennessee Infections Associated with Peanut Butter-United States, 2006-2007. Morbidity and Mortality Weekly Report 56, 521-525.

Holliday, S.L., Adler, B.B., Beuchat, L.R. 2003. Viability of Salmonella, Escherichia coli 0157:H7, and Listeria monocytogenes in butter, yellow fat spreads, and margarine as affected by temperature and physical abuse. Food Microbiology 20: 159-168.

Holliday, S.L. Beuchat, L.R. 2003 Viability of Salmonella, Escherichia coli 0157:H7, and Listeria monocytogenes in yellow fat spreads as affected by storage temperature. Journal of Food Protection 66:549-558.

Kieboom, J. Kusumaningrum, H.D. Tempelaars, M.H. Hazeleger, W.C. Abee, T. Beumer, R.R. 2006. Survival, elongation, and elevated tolerance of Salmonella enteric serovar enteritidis at reduced water activity. Journal of Food Protection 69: 26810-2686.

Lewis, S.J. Velasquez, A. Cuppett, S.L. McKee, S.R. 2002. Effect of Electron Beam Irradation on Poultry Meat Safety and Quality. Poultry Science. 81: 896-903.

${ }^{a}$ Mattick, K.L. Jorgensen, F. Legan, J.D. Lappin-Scott, H.M. Humphrey, T.J. 2000. Habituation of Salmonella spp. at Reduced Water Activity and Its Effect on Heat Tolerance. Applied and Environmental Microbiology 66: 4921-4925.

${ }^{b}$ Mattick, K.L. Jorgensen, F. Legan, J.D. Cole, M.B. Porter, J. Lappin-Scott, H.M. Humphrey, T.J. 2000. Survival and Filamentation of Salmonella enterica Serovar Enteritidis PT4 and Salmonella enteric Servovar Typhimurium DT104 at Low Water Activity. Applied and Environmental Microbiology 66: 1274-1279.

Mattick, K.L. Jorgensen, F. Wang, P. Pound, J. Vandeven, M.H. Ward, L.R Legan, J.D. LappinScott, H.M. Humphrey, T.J. 2001. Effect of Challenge Temperature and Solute Type on Heat Tolerance of Salmonella Serovars at Low Water Activity. Applied and Environmental Microbiology 67: 4128-4136.

Park, E.J. Oh, S.W. Kang, D.H. 2008. Fate of Salmonella Tennessee in Peanut Butter at 4 and $22^{\circ} \mathrm{C}$ Journal of Food Science 73: M82-M86.

Sarjeant, K.C. Williams, S.K. Hinton, A. 2005. The Effect of Electron Beam Irradiation on the Survival of Salmonella enteric servovar Typhimurium and Psychrotrophic Bacteria on Raw Chicken Breasts Stored at Four Degrees Celsius For Fourteen Days. Journal of Poultry Science. 84: 955-958. 
Table 1. Survival curves of Salmonella Tennessee populations (mean log CFU/g $\pm S D ; n=6$ ) in peanut butter plated on non-selective tryptic soy agar (TSA) with an initial inoculums of $10^{7}$.

\begin{tabular}{|c|c|c|c|c|c|}
\hline E-beam Dose & Day 2 & Day 4 & Day 6 & Day 8 & Day 14 \\
\hline $\mathbf{0}$ & $8.20 \pm 0.09^{1, \mathrm{a}}$ & $8.14 \pm 0.08^{1, \mathrm{a}}$ & $8.12 \pm 0.07^{1, \mathrm{a}}$ & $8.12 \pm 0.12^{1, \mathrm{a}}$ & $8.09 \pm 0.12^{1, a}$ \\
\hline 0.5 & $5.43 \pm 0.05^{1, b}$ & $5.34 \pm 0.18^{2, b}$ & $5.33 \pm 0.19^{2, b}$ & $5.38 \pm 0.14^{2, b}$ & $4.82 \pm 0.39^{3, b}$ \\
\hline 1 & $4.26 \pm 0.16^{1, \mathrm{c}, \mathrm{d}}$ & $4.23 \pm 0.08^{1, \mathrm{c}}$ & $4.30 \pm 0.22^{1, \mathrm{c}}$ & $4.22 \pm 0.06^{1, \mathrm{c}}$ & $3.79 \pm 0.48^{2, b}$ \\
\hline 1.5 & $4.46 \pm 0.08^{1, \mathrm{c}}$ & $3.72 \pm 0.19^{2, \mathrm{~d}}$ & $3.54 \pm 0.15^{2, \mathrm{~d}}$ & $3.50 \pm 0.06^{2, \mathrm{~d}}$ & $3.28 \pm 0.19^{3, c}$ \\
\hline 2 & $3.84 \pm 0.28^{1, \mathrm{~d}}$ & $3.34 \pm 0.10^{2, \mathrm{e}}$ & $3.45 \pm 0.22^{2, \mathrm{~d}}$ & $3.43 \pm 0.10^{2, \mathrm{~d}}$ & $3.31 \pm 0.08^{3, \mathrm{c}}$ \\
\hline 2.5 & $3.30 \pm 0.16^{1, \mathrm{e}}$ & $2.50 \pm 0.24^{2, \mathrm{f}}$ & $2.51 \pm 0.21^{2, \mathrm{e}}$ & $2.44 \pm 0.20^{2, \mathrm{e}}$ & $<1.0 * 10^{23, \mathrm{~d}}$ \\
\hline
\end{tabular}

${ }^{\mathrm{a}, \mathrm{b}, \mathrm{c}, \mathrm{d}, \mathrm{e}}$ Values designated with the same letter within a column are not significantly different $(\mathrm{P}<0.05)$.

${ }^{1,2,3,4}$ Values with different superscript numbers within rows indicate significant differences in within days $(P \leq 0.05)$. 
Table 2. Survival curves of Salmonella Tennessee populations (mean log CFU/g $\pm S D ; n=6$ ) in peanut butter plated on selective xylose lysine deoxycholate agar (XLD) with an initial inoculums of $10^{7}$.

\begin{tabular}{|c|c|c|c|c|c|}
\hline E-beam Dose & Day 2 & Day 4 & Day 6 & Day 8 & Day 14 \\
\hline $\mathbf{0}$ & $8.20 \pm 0.09^{1, a}$ & $8.10 \pm 0.30^{1, a}$ & $8.13 \pm 0.11^{1, \mathrm{a}}$ & $8.10 \pm 0.08^{1, a}$ & $8.04 \pm 0.14^{2, a}$ \\
\hline 0.5 & $4.30 \pm 0.11^{1, b}$ & $4.27 \pm 0.29^{1, b}$ & $4.62 \pm 0.76^{2, b}$ & $4.35 \pm 0.13^{1, b}$ & $3.87 \pm 0.42^{3, b}$ \\
\hline 1 & $4.19 \pm 0.11^{1, b}$ & $4.15 \pm 0.10^{1, b}$ & $4.10 \pm 0.16^{1, \mathrm{~b}}$ & $4.14 \pm 0.01^{1, \mathrm{~b}}$ & $3.86 \pm 0.53^{2, b}$ \\
\hline 1.5 & $4.32 \pm 0.11^{1, \mathrm{~b}}$ & $3.64 \pm 0.21^{2, \mathrm{c}}$ & $3.64 \pm 0.18^{2, \mathrm{c}}$ & $3.57 \pm 0.07^{2, \mathrm{c}}$ & $3.38 \pm 0.08^{3, c}$ \\
\hline 2 & $3.55 \pm 0.18^{1, \mathrm{c}}$ & $3.36 \pm 0.12^{2, \mathrm{c}}$ & $3.46 \pm 0.18^{1, \mathrm{c}}$ & $3.44 \pm 0.06^{1, \mathrm{c}}$ & $3.30 \pm 0.10^{2, \mathrm{c}}$ \\
\hline 2.5 & $1.54 \pm 0.15^{1, \mathrm{~d}}$ & $2.35 \pm 0.14^{2, \mathrm{~d}}$ & $2.31 \pm 0.09^{2, \mathrm{~d}}$ & $1.88 \pm 0.05^{1, \mathrm{~d}}$ & $<1.0 * 10^{23, \mathrm{~d}}$ \\
\hline
\end{tabular}

${ }^{\mathrm{a}, \mathrm{b}, \mathrm{c}, \mathrm{d}, \mathrm{e}}$ Values designated with the same letter within a column are not significantly different $(\mathrm{P}<0.05)$.

${ }^{1,2,3,4}$ Values with different superscript numbers within rows indicate significant differences in within days $(P \leq 0.05)$. 
Table 3. Survival curves of Salmonella Typhimurium populations (mean $\log C F U / g \pm S D$; $n=6$ ) in peanut butter plated on nonselective tryptic soy agar (TSA) with an initial inoculums of $10^{7}$.

\begin{tabular}{llllll}
\hline E-beam Dose & Day 2 & Day 4 & Day 6 & Day 8 & Day 14 \\
\hline $\mathbf{0}$ & $8.32 \pm 0.12^{1, \mathrm{a}}$ & $8.27 \pm 0.11^{1, \mathrm{a}}$ & $8.35 \pm 0.07^{1, \mathrm{a}}$ & $8.08 \pm 0.25^{2, \mathrm{a}}$ & $8.13^{2 \pm 0.11^{2, \mathrm{a}}}$ \\
$\mathbf{0 . 5}$ & $5.41 \pm 0.03^{1, \mathrm{~b}}$ & $5.13 \pm 0.19^{2, \mathrm{~b}}$ & $5.12 \pm 0.23^{2, \mathrm{~b}}$ & $5.16 \pm 0.17^{2, \mathrm{~b}}$ & $5.04^{2} \pm 0.11^{3, \mathrm{~b}}$ \\
$\mathbf{1}$ & $5.35 \pm 0.16^{1, \mathrm{~b}}$ & $4.22 \pm 0.20^{2, \mathrm{c}}$ & $4.30 \pm 0.09^{2, \mathrm{c}}$ & $4.27 \pm 0.06^{2, \mathrm{c}}$ & $3.89 \pm 0.33^{3, \mathrm{c}}$ \\
$\mathbf{1 . 5}$ & $4.49 \pm 0.15^{1, \mathrm{c}}$ & $4.29 \pm 0.21^{2, \mathrm{c}}$ & $4.22 \pm 0.25^{2, \mathrm{c}}$ & $4.22 \pm 0.16^{2, \mathrm{c}}$ & $3.44^{2} \pm 0.17^{3, \mathrm{~d}}$ \\
$\mathbf{2}$ & $4.04 \pm 0.29^{1, \mathrm{c}}$ & $3.8 \pm 0.06^{2, \mathrm{~d}}$ & $3.62 \pm 0.16^{3, \mathrm{~d}}$ & $3.50 \pm 0.21^{3, \mathrm{~d}}$ & $3.48^{2} \pm 0.05^{3, \mathrm{~d}}$ \\
$\mathbf{2 . 5}$ & $4.18 \pm 0.09^{1, \mathrm{c}}$ & $3.18 \pm 0.25^{2, \mathrm{e}}$ & $3.05 \pm 0.24^{2, \mathrm{e}}$ & $3.00 \pm 0.29^{2, \mathrm{e}}$ & $2.12^{2 \pm 0.37^{3, \mathrm{e}}}$ \\
\hline
\end{tabular}

${ }^{\mathrm{a}, \mathrm{b}, \mathrm{c}, \mathrm{d}, \mathrm{e}}$ Values designated with the same letter within a column are not significantly different $(\mathrm{P}<0.05)$.

${ }^{1,2,3,4}$ Values with different superscript numbers within rows indicate significant differences in within days $(P \leq 0.05)$. 
Table 4. Survival curves of Salmonella Typhimurium populations (mean log CFU/g $\pm S D ; n=6$ ) in peanut butter plated on selective xylose lysine deoxycholate agar (XLD) with an initial inoculums of $10^{7}$.

\begin{tabular}{llllll}
\hline E-beam Dose & Day 2 & Day 4 & Day 6 & Day 8 & Day 14 \\
\hline $\mathbf{0}$ & $8.25 \pm 0.14^{1, \mathrm{a}}$ & $8.21 \pm 0.11^{1, \mathrm{a}}$ & $8.31 \pm 0.07^{1, \mathrm{a}}$ & $8.21 \pm 0.09^{1, \mathrm{a}}$ & $8.07 \pm 0.11^{2, \mathrm{a}}$ \\
$\mathbf{0 . 5}$ & $5.32 \pm 0.16^{1, \mathrm{~b}}$ & $4.60 \pm 0.12^{2, \mathrm{~b}}$ & $4.62 \pm 0.04^{2, \mathrm{~b}}$ & $4.66 \pm 0.06^{2, \mathrm{~b}}$ & $4.52^{2 \pm 0.04^{2, \mathrm{~b}}}$ \\
$\mathbf{1}$ & $4.77 \pm 0.17^{1, \mathrm{c}}$ & $3.56 \pm 0.12^{2, \mathrm{c}}$ & $3.68 \pm 0.09^{2, \mathrm{c}}$ & $3.77 \pm 0.33^{2, \mathrm{c}}$ & $3.46 \pm 0.04^{3, \mathrm{c}}$ \\
$\mathbf{1 . 5}$ & $4.42 \pm 0.07^{1, \mathrm{c}}$ & $3.74 \pm 0.24^{2, \mathrm{c}}$ & $3.76 \pm 0.32^{2, \mathrm{c}}$ & $3.76 \pm 0.22^{2, \mathrm{c}}$ & $3.41 \pm 0.12^{3, \mathrm{c}}$ \\
$\mathbf{2}$ & $3.90 \pm 0.32^{1, \mathrm{~d}}$ & $3.60 \pm 0.15^{1, \mathrm{c}}$ & $3.41 \pm 0.14^{2, \mathrm{~d}}$ & $3.43 \pm 0.04^{2, \mathrm{~d}}$ & $3.33^{2 \pm 0.05^{3, \mathrm{c}}}$ \\
$\mathbf{2 . 5}$ & $3.43 \pm 0.10^{1, \mathrm{~d}}$ & $2.54 \pm 0.15^{2, \mathrm{~d}}$ & $2.61 \pm 0.14^{2, \mathrm{e}}$ & $2.54 \pm 0.12^{2, \mathrm{e}}$ & $<1.0^{*} 10^{2, \mathrm{~d}}$ \\
\hline
\end{tabular}

${ }^{\mathrm{a}, \mathrm{b}, \mathrm{c}, \mathrm{d}, \mathrm{e}}$ Values designated with the same letter within a column are not significantly different $(\mathrm{P}<0.05)$.

1,2,3,4 Values with different superscript numbers within rows indicate significant differences in within days $(P \leq 0.05)$. 
Figure 1. Salmonella Tennessee survivors in peanut butter subjected to electron beam on TSA over a 14 day period.

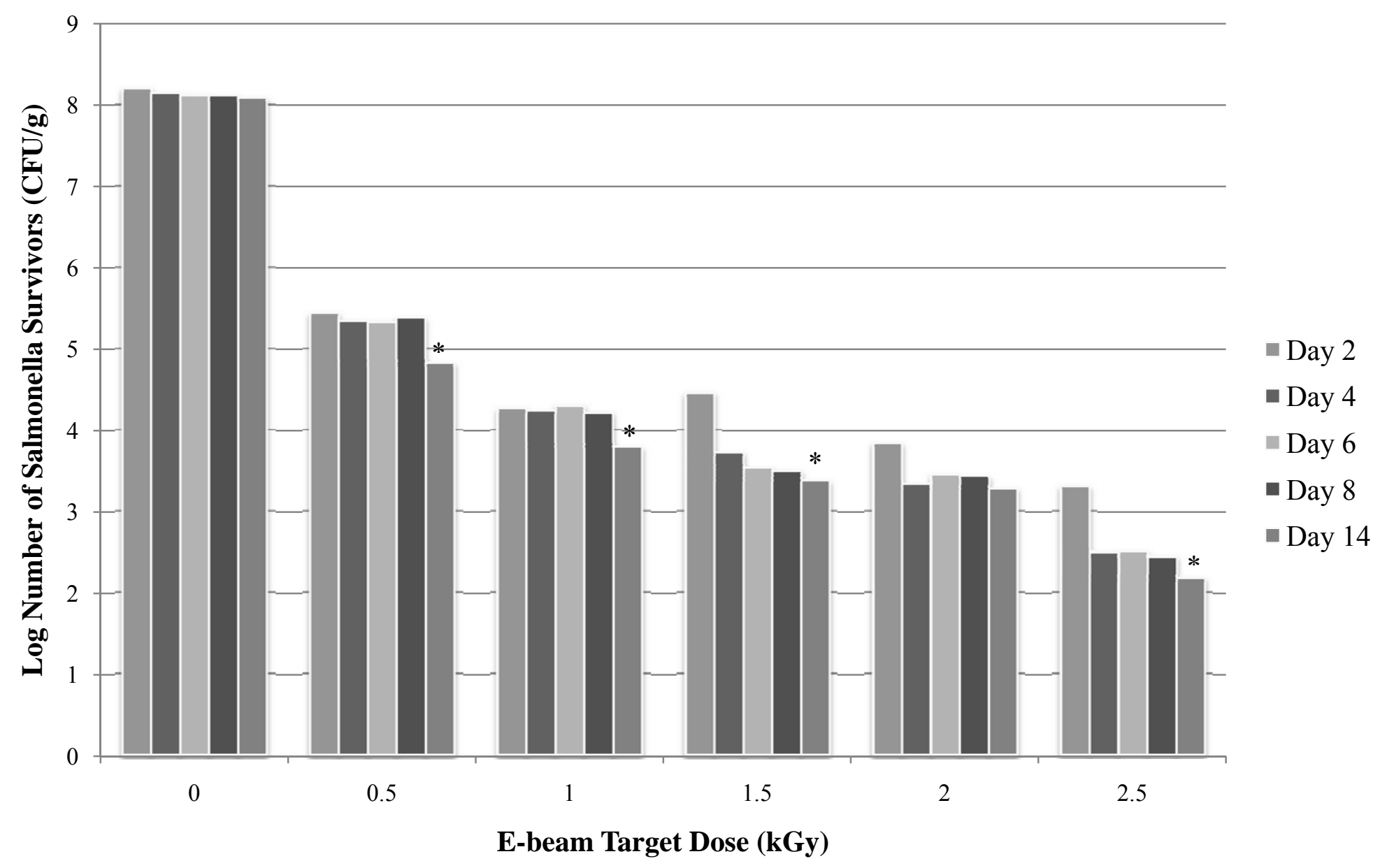


Figure 2. Salmonella Tennessee survivors in peanut butter subjected to electron beam on XLD over a 14 day period.

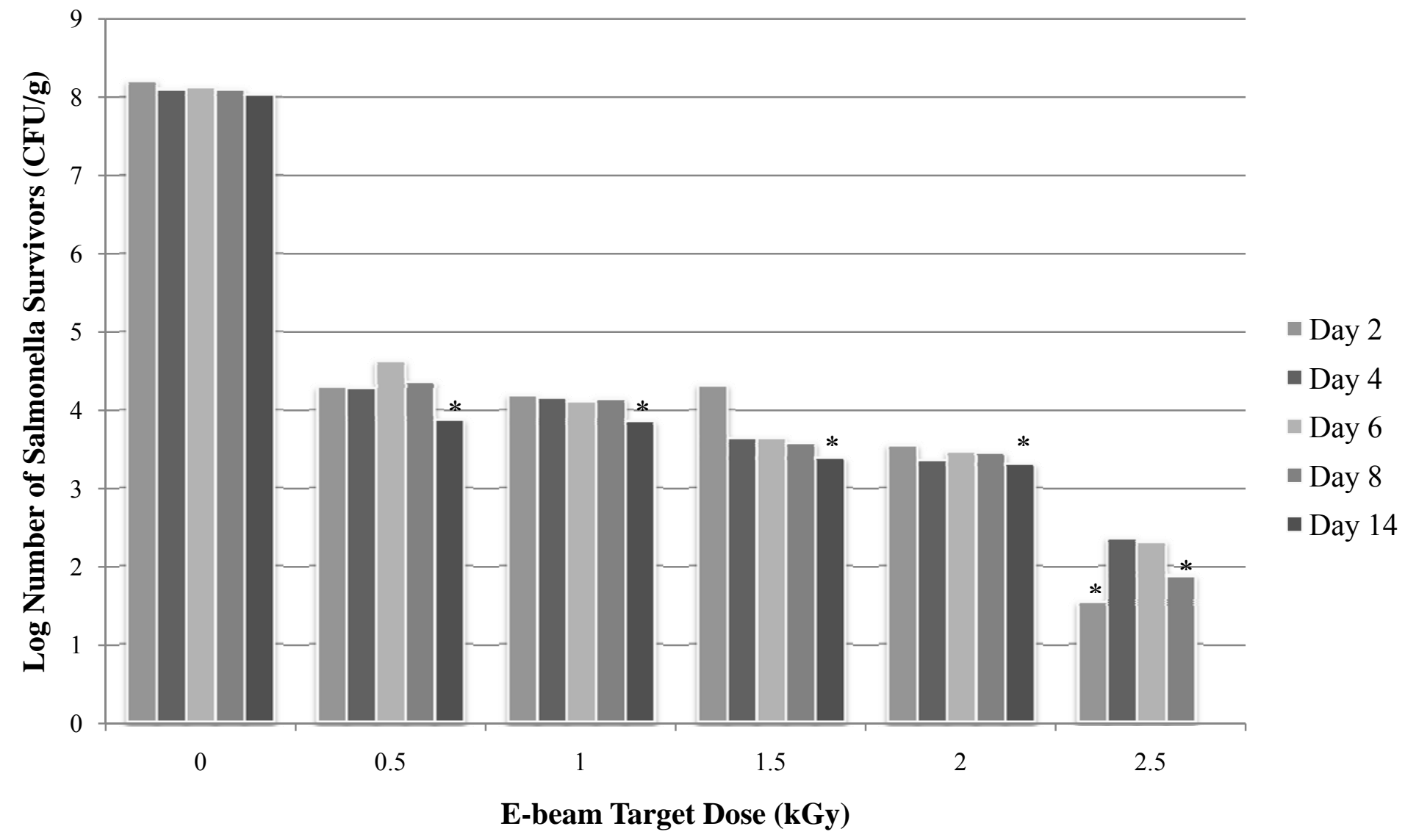


Figure 3. Salmonella Typhimurium survivors in peanut butter subjected to electron beam on TSA over a 14 day period.

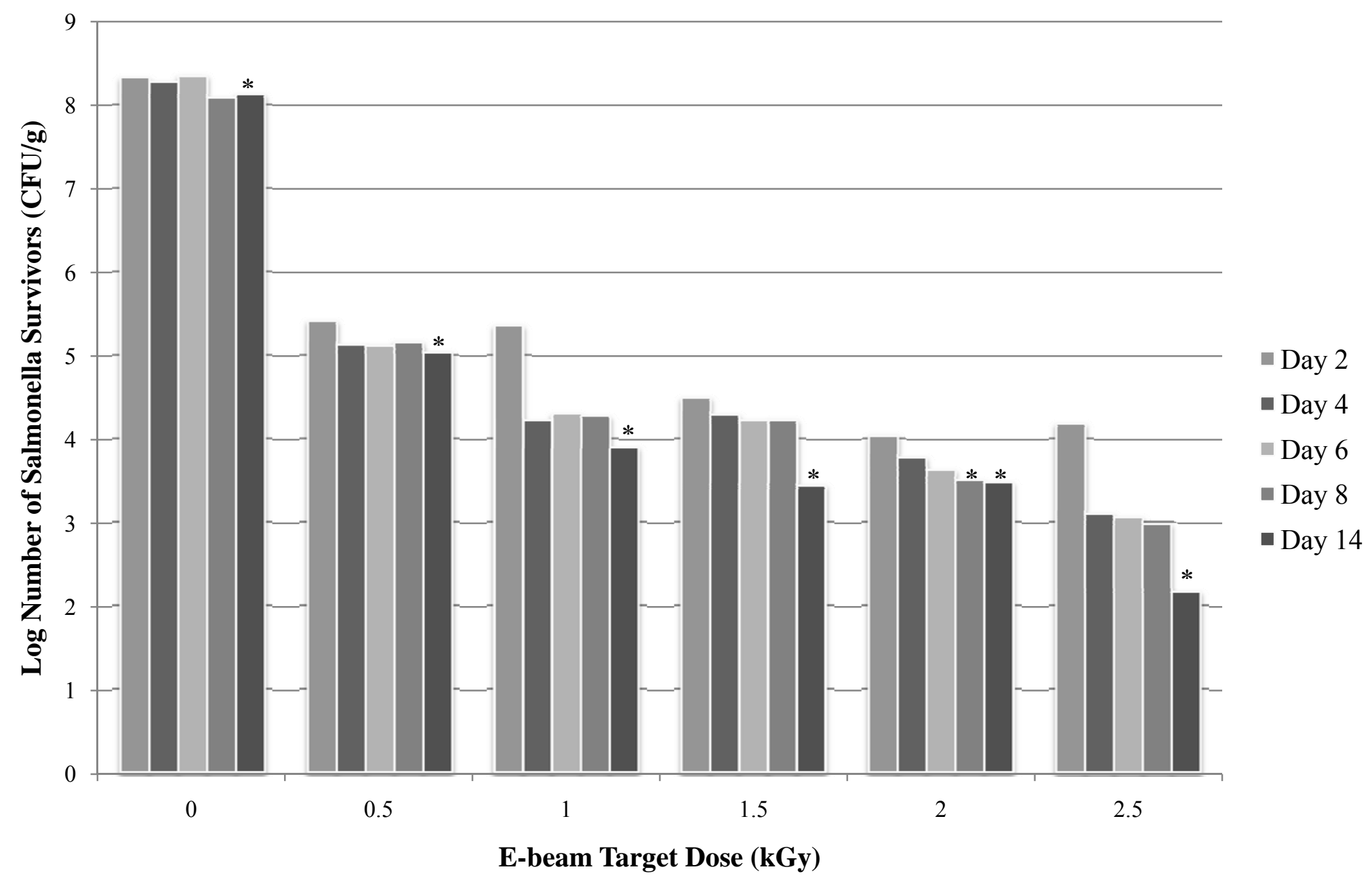


Figure 4. Salmonella Typhimurium survivors in peanut butter subjected to electron beam on XLD over a 14 day period.

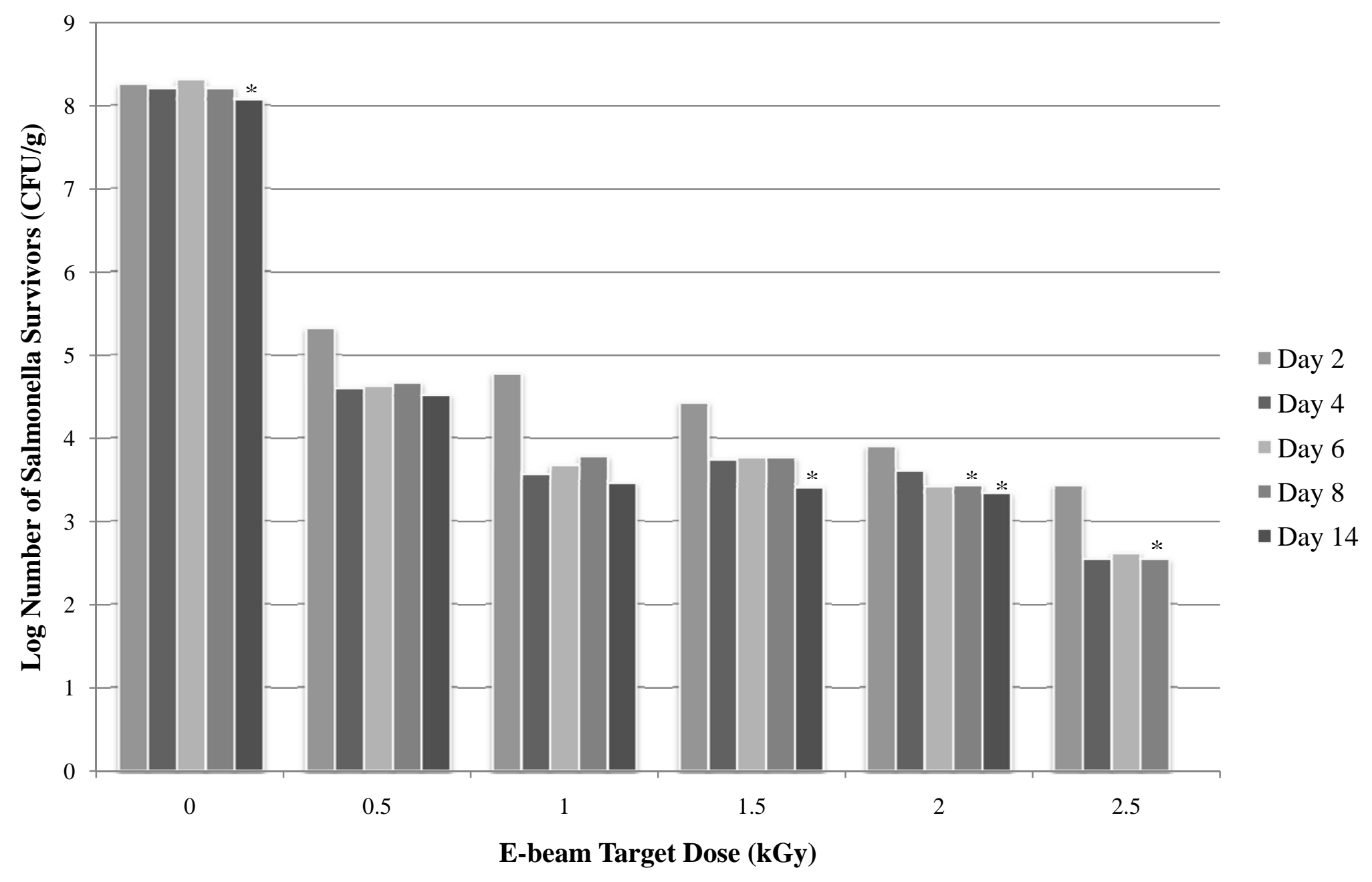




\section{APPENDIX A}

Survivor curve for Salmonella Tennessee in peanut butter subjected to electron beam on TSA. Bars on the data points indicate standard error.

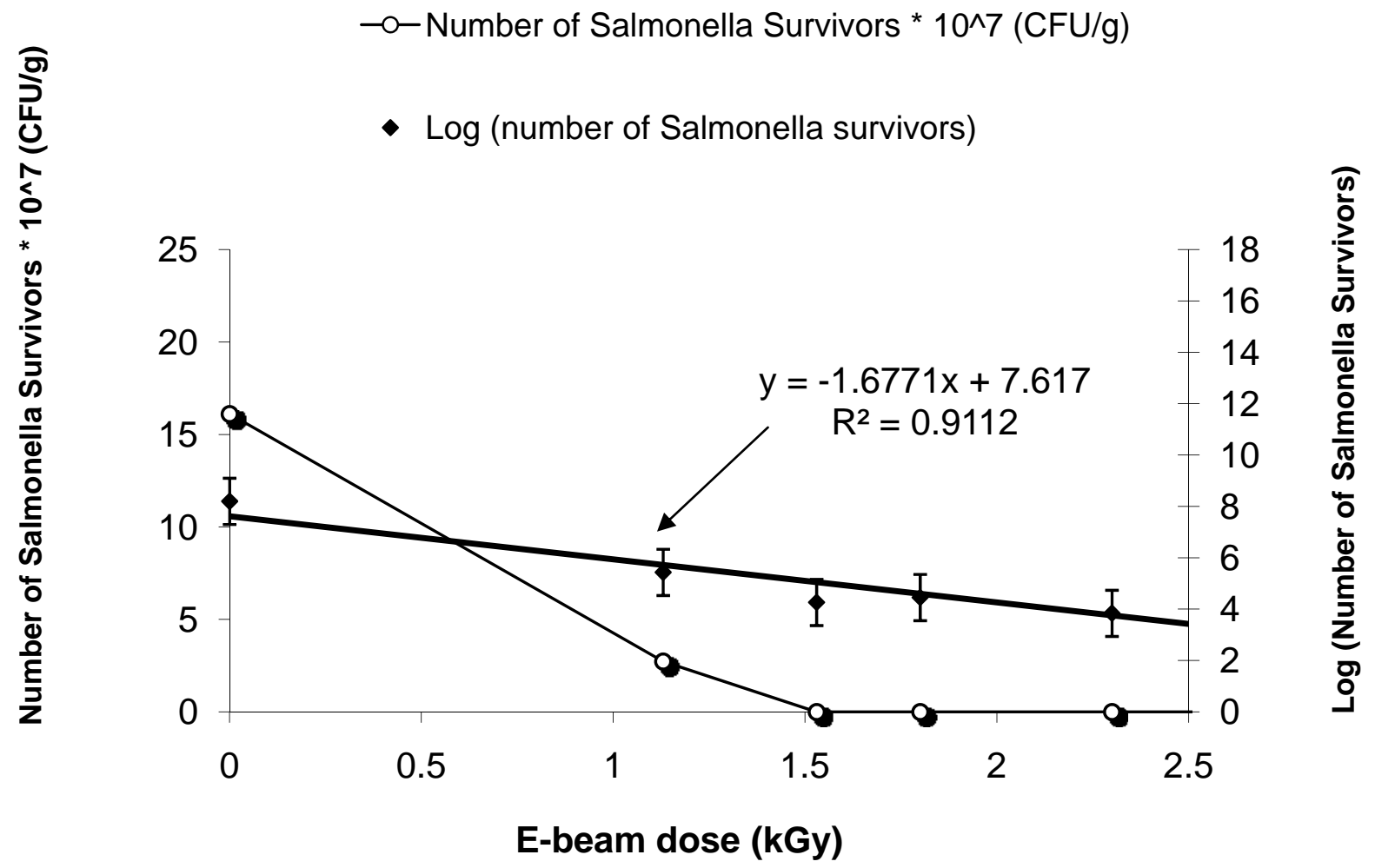




\section{APPENDIX B}

Survivor curve for Salmonella Tennessee in peanut butter subjected to electron beam on XLD. Bars on the data points indicate standard error.

- Log (number of Salmonella survivors)

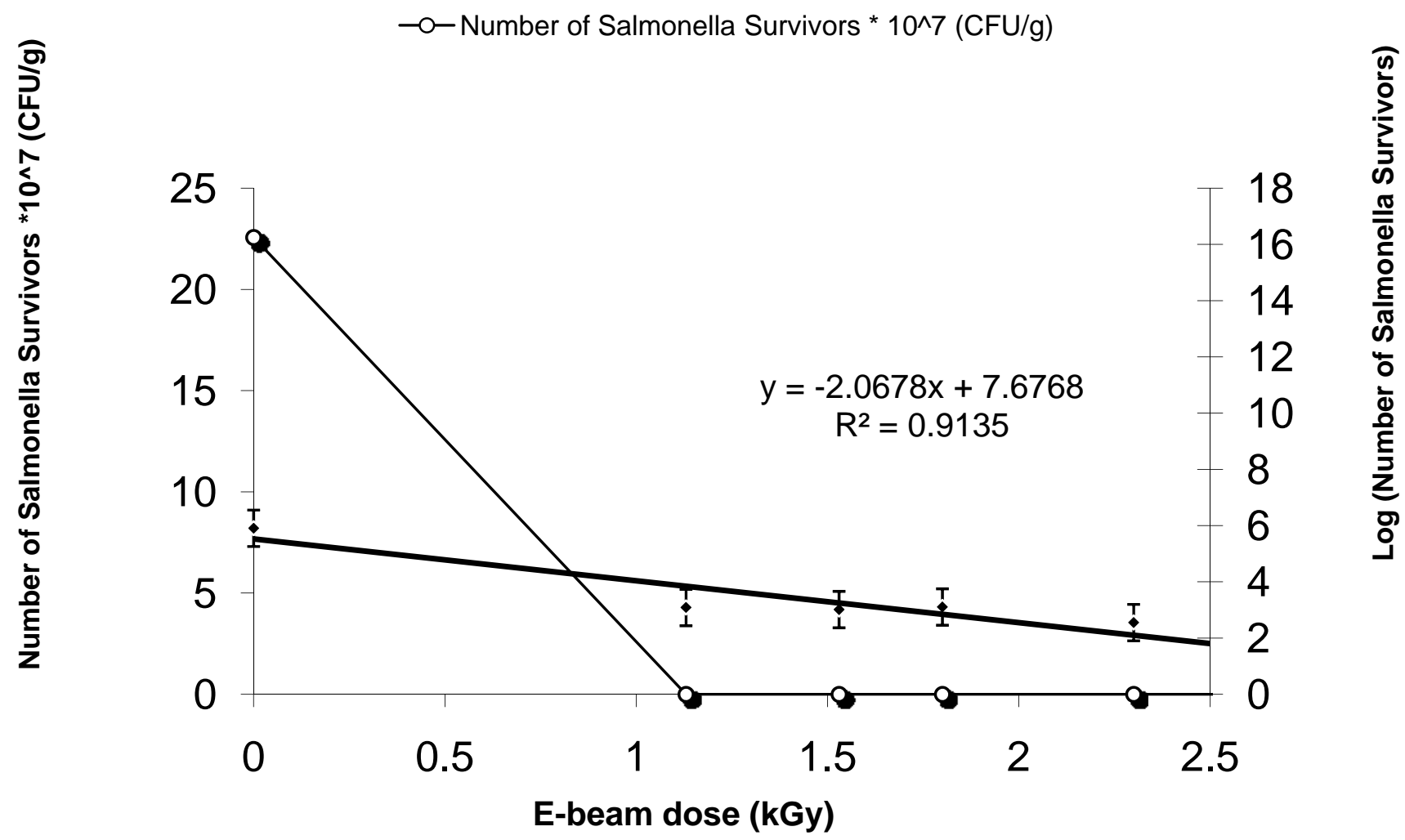




\section{APPENDIX C}

Survivor curve for Salmonella Typhimurium in peanut butter subjected to electron beam on TSA. Bars on the data points indicate standard error.

$-0-$ Number of Salmonella Survivors * 10^7 (CFU/g)

- Log (number of Salmonella survivors)

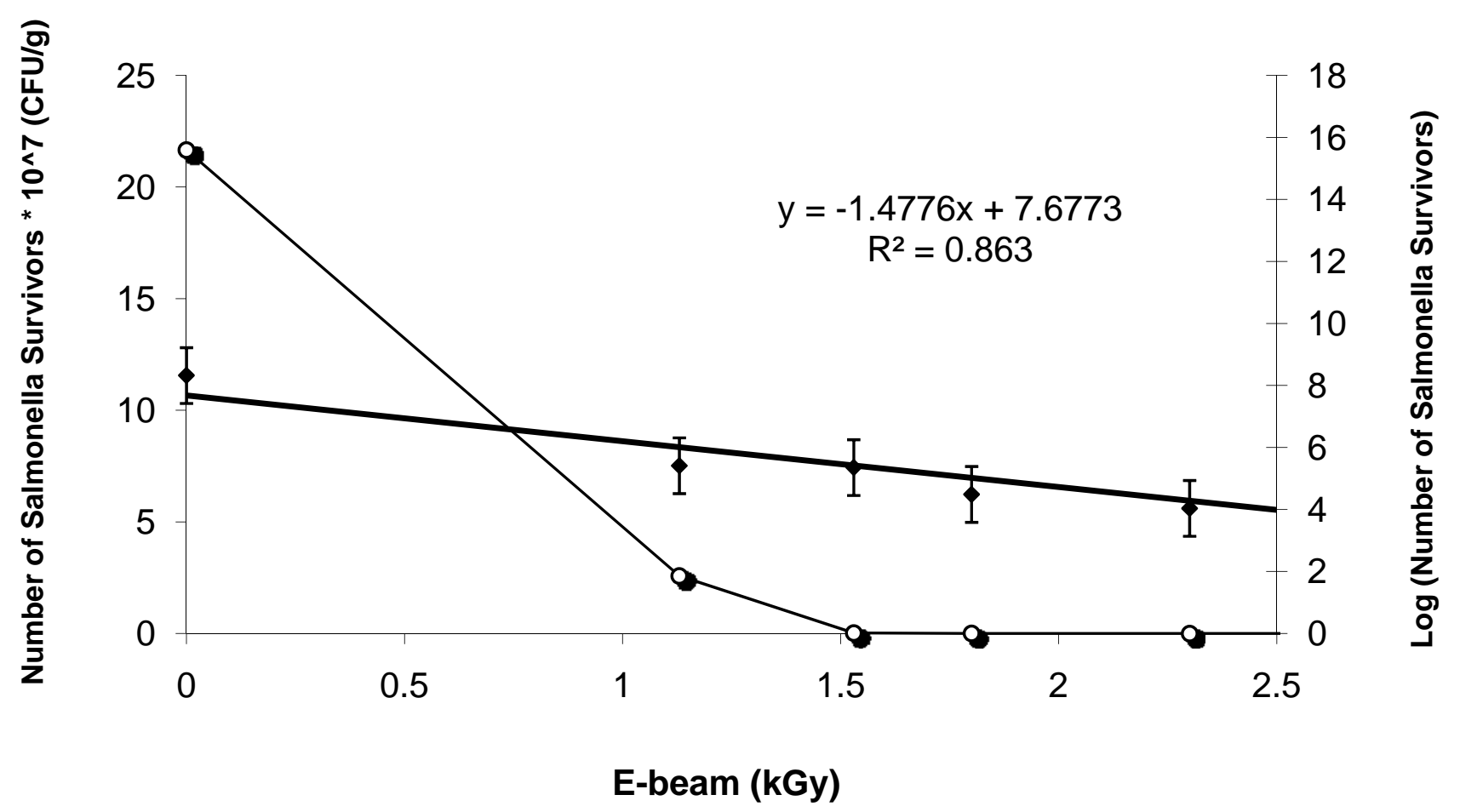




\section{APPENDIX D}

Survivor curve for Salmonella Typhimurium in peanut butter subjected to electron beam on XLD. Bars on the data points indicate standard error.

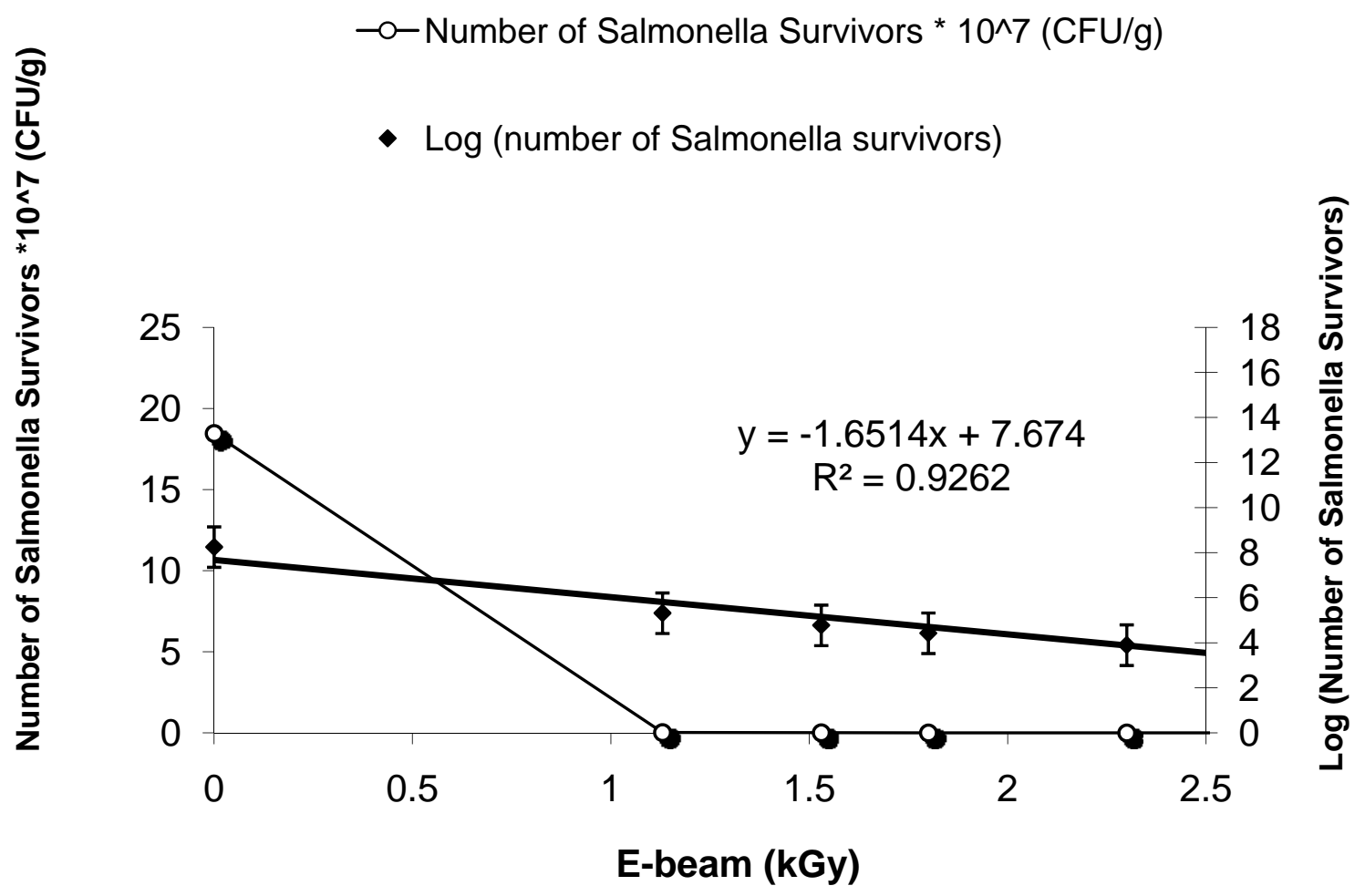


Vitae

Andrea Lynn Hvizdzak was born and raised in Colliers, WV. She graduated from Brooke High School, Wellsburg, WV in May of 2003. She earned a Bachelor's degree in Human Nutrition and Foods from West Virginia University in December 2007. Andrea continued her education to pursue a Master's degree at West Virginia University in Animal and Nutritional Sciences. 